\title{
VARIATION OF SUMMER PHYTOPLANKTON COMMUNITY \\ 2 COMPOSITION AND ITS RELATIONSHIP TO NITRATE AND REGENERATED NITROGEN ASSIMILATION ACROSS THE NORTH 4 ATLANTIC OCEAN
}

6

N. Van Oostende ${ }^{1}$, S. E. Fawcett ${ }^{1,2}$, D. Marconi ${ }^{1}$, J. Lueders-Dumont ${ }^{1}$, A. J. M.

8 Sabadel $^{3,4}$, E. M. S. Woodward ${ }^{4}$, B. F. Jönsson ${ }^{1}$, D. M. Sigman ${ }^{1}$ and B. B. Ward ${ }^{1}$

$10{ }^{1}$ Department of Geosciences, Princeton University, Princeton New Jersey, USA

2 Department of Oceanography, University of Cape Town, Cape Town, South Africa

$12{ }^{3}$ Department of Chemistry, University of Otago, Dunedin, New Zealand

4 Plymouth Marine Laboratory, Plymouth, United Kingdom

14

contact email: oostende@Princeton.EDU

16

(C) 2016. This manuscript version is made available under the Elsevier user license http://www.elsevier.com/open-access/userlicense/1.0/ 


\section{Abstract}

19 The North Atlantic Ocean is considered a nitrogen (N) limited system once vernal 20 stabilisation of the water column alleviates light limitation and allows

21 phytoplankton growth to deplete surface nutrients to virtually undetectable levels.

22 Ammonium and other regenerated $\mathrm{N}$ forms are then the main surface $\mathrm{N}$ source for

23 phytoplankton production. The effort to determine which phytoplankton groups

24 contribute to long-term biological export production would be greatly aided by

25 information on which phytoplankton groups are responsible for the assimilation of

26 nitrate, as opposed to those assimilating predominantly regenerated N. In this study,

27 we used the natural abundance $\mathrm{N}$ isotopes to examine basin-scale patterns of nitrate

28 and regenerated $\mathrm{N}$ assimilation and evaluated the relationships between these

29 trends and phytoplankton community composition. Samples were collected during a

30 summertime cruise transect (August-September 2013) from the subtropical $\left(36^{\circ} \mathrm{N}\right.$

$\left.3173^{\circ} \mathrm{W}\right)$ to the subarctic $\left(54^{\circ} \mathrm{N} 20^{\circ} \mathrm{W}\right)$ North Atlantic and analysed for the $\mathrm{N}$ isotopic

32 composition ( $\delta^{15} \mathrm{~N}$ vs. $\mathrm{N}_{2}$ in air) of particulate nitrogen $(\mathrm{PN})$ and nitrate, size-

33 fractionated chlorophyll $a$, and phytoplankton group biomass using flow cytometry.

34 The depth of the $300 \mathrm{nmol} \mathrm{l}^{-1}$ nitrate isopleth shoaled from the subtropics $(79 \mathrm{~m})$,

35 where phytoplankton stripped surface waters of nitrate, to the subarctic, where it

36 intersected with the surface and the upward nutrient supply drove a summer

37 phytoplankton bloom. The $\delta^{15} \mathrm{~N}$ of $\mathrm{PN}$ above the nitracline increased from the 38 subtropics $(-0.3 \% 0)$ to the subarctic (4.2\%0), reflecting both a change in the $\delta^{15} \mathrm{~N}$ of 39 the subsurface nitrate source (from $2.4 \%$ to $5.1 \%$ ) and increased reliance by 40 phytoplankton on nitrate relative to regenerated N. Throughout the transect, the 41 phytoplankton community was mainly composed of pico- and nano-sized cells 42 ( $>88 \%$ of chlorophyll $a$ in the $<20 \mu \mathrm{m}$ size fraction). In the part of the transect 43 southwest of the Grand Banks, Prochlorococcus and Synechococcus together 44 dominated the picophytoplankton biomass (58\% and $18 \%$ on average) and 45 comprised $35 \%$ and 9\%, respectively, of combined pico- and nanophytoplankton

46 biomass. Pico- and nanoeukaryotes showed the opposite pattern, becoming more 
47 important closer to the subarctic (up to $31 \%$ and $86 \%$ of combined pico- and 48 nanophytoplankton biomass, respectively). The North Atlantic summertime

49 patterns in $\mathrm{N}$ assimilation implied by the $\mathrm{N}$ isotopes were consistent with a higher

50 degree of nitrate assimilation by larger eukaryotic cells and greater reliance on

51 regenerated $\mathrm{N}$ by cyanobacterial picophytoplankton, congruent with the observed

52 biomass distributions.

53

\section{Keywords:}

55 nitrate utilization, nitrogen assimilation, nitrogen isotopes, phytoplankton

56 community composition, flow cytometry, North Atlantic Ocean

\section{1. Introduction}

According to the classical paradigm, the amount of new production, which

61 drives the biological pump, is controlled by light intensity, the supply rate of nitrate

62 and other nutrients (phosphorus, iron) to the euphotic zone, and the degree to

63 which these nutrients are consumed by phytoplankton (Dugdale and Goering,

64 1967). In contrast, regenerated production is supported by forms of nitrogen (N)

65 recycled in the euphotic zone (predominantly ammonium and urea (Saito et al., 66 2014), and potentially augmented by in situ ammonia and nitrite oxidation) and,

67 from a mass balance perspective, does not contribute to long-term export 68 production (Eppley and Peterson, 1979). Dinitrogen $\left(\mathrm{N}_{2}\right)$ fixation, atmospheric 69 deposition and riverine input also contribute reactive $\mathrm{N}$ species that fuel new 70 production, but their annual flux to the surface ocean is minor compared to that of 71 subsurface nitrate in the North Atlantic Ocean (Altieri et al., 2016; Deutsch et al., 72 2007; Duce et al., 2008; Gruber and Sarmiento, 1997; Oschlies, 2002).

73 Understanding the mechanisms responsible for the patterns of primary production

74 and nutrient cycling in the ocean in part requires improved knowledge of the spatial 75 distribution of biodiversity and its associated biogeochemical activities. 
76 Phytoplankton have adapted to thrive in the range of nutrient regimes -from 77 oligotrophic to mesotrophic- and light regimes -from stable low- or high-light 78 conditions to highly variable conditions- that occur in the ocean. Seasonal changes 79 in insolation and heat flux, major hydrographic features such as ocean currents and 80 fronts, as well as shorter-lived mesoscale eddies and meteorological events all 81 structure the distribution of phytoplankton assemblages and shape their nutrient 82 uptake potential across the oceans (d'Ovidio et al., 2010; Garçon et al., 2001; 83 Sambrotto et al., 1993). In turn, the species composition and cell size structure of 84 the plankton assemblage are often characteristic of their immediate environment 85 and its physicochemical history.

86 The North Atlantic Ocean is classically considered an N-limited system 87 (Moore et al., 2013), becoming N and $\mathrm{P}$ co-limited further south (e.g. Moore et al. 88 (2008)) and N and Fe co-limited further north (e.g. Nielsdóttir et al. (2009)), once 89 the water column stratifies in spring and summer and phytoplankton are released 90 from the light limitation of winter. The North Atlantic spring bloom constitutes one 91 of the largest biological signals on Earth and is characterised by a succession of 92 phytoplankton groups (Lochte et al., 1993; Sieracki et al., 1993). The decreasingly 93 turbulent, nutrient-rich, springtime conditions are characterised by fast-growing 94 diatom-dominated planktonic communities associated with high rates of new 95 production and export production until silicate is exhausted (Alkire et al., 2014; 96 Cetinić et al., 2015; Rynearson et al., 2013). These high-biomass diatom blooms are 97 then succeeded by communities of smaller phytoplankton species (e.g., 98 coccolithphores) and mixotrophic flagellate species (e.g., dinoflagellates) in the 99 more quiescent and nutrient-deplete summertime conditions, or in water masses 100 originating from the subtropics (Barton et al., 2013; Dandonneau et al., 2004; Tarran 101 et al., 2001).

102 At lower chlorophyll $a$ concentrations ([Chla]<1 $\mathrm{mg} \mathrm{m}^{-3}$ ), which are typically 103 observed in low nutrient supply systems, the smallest nano- and picophytoplankton 104 size-fractions make up the largest share of total Chla (Chisholm, 1992; Marañón et 105 al., 2012; Raimbault et al., 1988). The dominance of the pico- and 106 nanophytoplankton biomass in this case is reflected in their substantial contribution 
107 to primary productivity (Joint et al., 1993; Marañon et al., 2001). Beyond the 108 partitioning of phytoplankton functional groups into size classes (Sieburth et al., 109 1978), techniques such as flow cytometry have allowed quantification of at least 110 some of their considerable phylogenetic and functional diversity (e.g., the

111 distinction between phycoerythrin-containing cyanobacteria and coccolithophores), 112 therefore allowing for extensive sampling and recognition of macro-ecological 113 patterns in phytoplankton community structure (Li, 1997, 2002; Tarran et al., 114 2006). The picophytoplankton community (cell diameter $<\sim 2-3 \mu \mathrm{m}$ ), of which the 115 prokaryotic cyanobacterial genera Prochlorococcus and Synechococcus are usually 116 numerically dominant, also harbours a considerable amount of eukaryotic diversity 117 (Hooks et al., 1988; Kirkham et al., 2013; Vaulot et al., 2008). The larger cell size of 118 these eukaryotes means that, although they are typically less numerically-abundant 119 than the very small picocyanobacteria (cell diameter $\sim 0.6-1.2 \mathrm{um}$ ), they often 120 dominate the phytoplankton biomass (Li, 1995). The relatively larger 121 nanophytoplankton, on the other hand, have only fairly recently been routinely 122 measured using flow cytometry instead of epifluorescence microscopy or 123 concentrations of marker pigments (Tarran et al., 2006), which has allowed for 124 higher sample throughput. The combination of phytoplankton community analysis 125 with estimates of phytoplankton group biomass based on flow cytometric size 126 measurements allows for a more quantitative understanding of the functioning of 127 microbial communities (Laney and Sosik, 2014; Olson et al., 1989; Rodríguez et al., 128 1998; Zubkov et al., 1998).

129 Intense biological activity during the spring and early summer in the North 130 Atlantic depletes the surface nutrients (Joint et al., 1993), and nutrient resupply 131 from deeper waters is hampered by further strengthening of the pycnocline. This 132 leads to microbial communities becoming increasingly dependent on regenerated 133 forms of $\mathrm{N}$ for growth, such that they contribute less to new-, and by extension 134 export-, production (Azam et al., 1983; Eppley and Peterson, 1979; Pomeroy, 1974). 135 However, some phytoplankton groups appear to be effective at assimilating nitrate 136 at the low concentrations available at the base of the euphotic zone in oligotrophic 137 systems, and/or contribute disproportionally to carbon export. For example, 
138 pigment data from the subtropical North Atlantic suggest that nanoeukaryotes 139 contribute equally to particulate organic carbon (POC) export and autotrophic 140 biomass, while cyanobacteria contributions to POC export are one-tenth of their 141 contribution to autotrophic biomass (Lomas and Moran, 2011). Moreover, recent 142 observations from the western and eastern subtropical North Atlantic have shown 143 the importance of picoeukaryotes in nitrate assimilation and their potential for 144 export production compared to prokaryotic phytoplankton (Fawcett et al., 2011;

145 Painter et al., 2014), even when euphotic zone nitrate concentrations are below the 146 limit of conventional colorimetric detection techniques. These findings emphasise 147 the need for investigation of the distribution and abundance of the diverse 148 picoeukaryotic phytoplankton from oligo- to mesotrophic oceanic regimes.

149 Phytoplankton growth and community structure are closely linked to the 150 availability and biogeochemistry of $\mathrm{N}$. Natural variations in the $\mathrm{N}$ isotopes of nitrate 151 and suspended particulate $\mathrm{N}(\mathrm{PN})$ provide an integrative view of the $\mathrm{N}$ cycling 152 activity of upper ocean biota. Regional and local differences in the supply of $\mathrm{N}$ to the 153 euphotic zone as either subsurface nitrate or recycled $\mathrm{N}$ will be reflected in the $\delta^{15} \mathrm{~N}$ 154 of PN $\left(\delta^{15} \mathrm{~N}\right.$, in per mille (\%o) vs. $\mathrm{N}_{2}$ in air, $=\left\{\left[\left({ }^{15} \mathrm{~N} /{ }^{14} \mathrm{~N}\right)\right.\right.$ sample $\left.\left./\left({ }^{15} \mathrm{~N} /{ }^{14} \mathrm{~N}\right)_{\text {air }}\right]-1\right\} \times$ 155 1000). Under nitrate-deplete summertime conditions, $\mathrm{N}$ forms regenerated by 156 euphotic zone biota (predominantly ammonium) are thought to support most 157 phytoplankton growth (Dugdale and Goering, 1967; Eppley and Peterson, 1979).

158 The $\delta^{15} \mathrm{~N}$ of ammonium produced by surface ocean recycling is inferred to be low 159 based on the amplitude of the isotopic fractionation associated with its production 160 (Checkley and Miller, 1989; Macko et al., 1986; Silfer et al., 1992). In addition to 161 assimilation by phytoplankton, another possible fate for euphotic zone ammonium 162 is oxidation to nitrite and then nitrate (i.e., nitrification), which has the potential to 163 complicate estimates of new production (Yool et al., 2007). However, like recycled 164 ammonium, nitrate regenerated in euphotic zone waters will be low in $\delta^{15} \mathrm{~N}$ (DiFiore 165 et al., 2009; Fawcett et al., 2011). This is because the combined isotope effect of 166 ammonia and nitrite oxidation is significantly greater than that of ammonium and 167 nitrite assimilation (14-19\%o vs. 0-3\%o; Casciotti, 2009; Casciotti et al., 2003; Hoch 
168 et al., 1992; Liu et al., 2013; Mariotti et al., 1981; Pennock et al., 1996), resulting in

169 low- $\delta^{15} \mathrm{~N} N$ being preferentially channelled into the nitrate pool (Suppl. Text 2.1).

170 Thus, the assimilation of recycled $\mathrm{N}$, be it ammonium or regenerated nitrate, will

171 produce euphotic zone PN that is low in $\delta^{15} \mathrm{~N}$.

172 The $\delta^{15} \mathrm{~N}$ of subsurface ocean nitrate ranges between $2.4 \%$ and $5.1 \%$ in our 173 study region (see below; Marconi et al., 2015). In the case of a high degree of 174 consumption of the gross nitrate supply and lacking substantial assimilation of 175 other (e.g., regenerated) $\mathrm{N}$ sources, the $\delta^{15} \mathrm{~N}$ of surface PN should approximate the $176 \delta^{15} \mathrm{~N}$ of this source nitrate (Altabet and Francois, 1994). Thus, suspended PN 177 comprising mainly nitrate-assimilating phytoplankton will have a higher $\delta^{15} \mathrm{~N}$ than if 178 the main phytoplankton $\mathrm{N}$ source had been regenerated N (Altabet, 1988; Fawcett et 179 al., 2011). Concomitant measurements of the $\delta^{15} \mathrm{~N}$ of PN and nitrate can therefore 180 offer a spatiotemporally integrated view of upper ocean $\mathrm{N}$ consumption and provide 181 more information about $\mathrm{N}$ transformation processes than measurements of $\mathrm{N}$ 182 concentrations alone.

183 The goal of this study was to determine the basin-scale patterns of $\mathrm{N}$ 184 assimilation across the North Atlantic Ocean and its relationship to the 185 phytoplankton community size-structure and composition. To this end, we assessed 186 primary production and $\mathrm{N}$ cycling using a suite of physical, ecological, 187 biogeochemical and isotopic measurements made along a summer transect from the 188 subtropical to the subarctic North Atlantic Ocean (Figure 1). We hypothesised that 189 the relative dominance of the phytoplankton community by pico- and 190 nanoeukaryotes, compared to cyanobacterial picophytoplankton, would increase 191 towards the subarctic North Atlantic in parallel with an increase in nitrate 192 assimilation as recorded by the $\delta^{15} \mathrm{~N}$ of upper ocean nitrate and PN.

\section{2. Methods and Materials}

The cruise transect was carried out in late summer of 2013 (23rd of August

196 to 3rd of September) on board the $R / V$ Endeavor, which sailed from Morehead City, 
197 North Carolina $\left(34.7^{\circ} \mathrm{N} 76.7^{\circ} \mathrm{W}\right)$ to the subarctic North Atlantic $\left(54.0^{\circ} \mathrm{N} 20.4^{\circ} \mathrm{W}\right)$

198 (Figure 1). Daily conductivity-temperature-density (CTD) casts to $1000 \mathrm{~m}$ depth 199 were performed at dawn, at 12 stations, at intervals of approximately 220 nautical 200 miles ( $\sim 410 \mathrm{~km}$; table 1$)$. At each station, water for the determination of chemical 201 and biological variables was collected from 9 depths using a set of 12 Niskin bottles 202 (30 l capacity). Surface water samples (5 m depth) were collected via the ship's 203 clean seawater inflow at each station, and every 6 hours along the transect. Results 204 from chemical, biological, and CTD measurements are available at BCO-DMO: 205 http://www.bco-dmo.org/project/544343.

\section{2.1. Hydrographic parameters}

The depth of the mixed layer (MLD) was derived using a difference in density 208 threshold of $0.045 \mathrm{~kg} \mathrm{~m}^{-3}$ from the water density value at $10 \mathrm{~m}$ depth (cf. de Boyer 209 Montégut et al. (2004)). Because most CTD casts were performed at dawn, the 210 euphotic zone depth $\left(\mathrm{Z}_{\mathrm{eu}}\right)$, which we define as the depth at which light intensity is $2111 \%$ of its surface value, was derived from each vertical chlorophyll $a$ (Chla) profile 212 (see below) by progressively integrating the water column Chla content [ $\Sigma \mathrm{Chla}$ ] to 213 simultaneously obtain [ $\Sigma \mathrm{Chla}$ ] and $\mathrm{Z}_{\text {eu }}$ through an iterative process (described by 214 Morel and Berthon (1989) and re-parameterised in Morel and Maritorena (2001)).

215 Based on the work of Marra et al. (2014) in the western North Atlantic, and 216 according to equation 3 in Boss and Behrenfeld (2010),

$217 Z_{I c}=\log _{10}(0.17 / 0.98 \times P A R) \times\left(Z_{\text {eu }} / \log _{10}(0.01)\right)$,

218 we assumed 0.17 moles quanta $\mathrm{m}^{-2}$ day $^{-1}$ to be the compensation irradiance (Ic) 219 below which light is insufficient to support net photoautotrophy. Although this Ic 220 value may be an underestimate (Laws et al., 2014), it encompassed the depth of 221 maximum Chla concentration at the southwestern stations of our transect and did 222 not significantly affect the [ $\Sigma \mathrm{Chla}]$ at the northeastern stations compared to higher 223 Ic values found in the literature (cf. Letelier et al. (2004)). This light compensation 224 depth $\left(Z_{\text {Ic }}\right)$, the lower boundary of a stratum of constant daily integrated photon 225 flux, was calculated using the previously-estimated $Z_{e u}$ and the surface daily 226 integrated photosynthetically available radiation (PAR) values obtained from NASA 
227 Aqua Modis level 3 data. Because of the small light attenuation coefficient derived at

228 station 7, the bottom depth was used instead of $\mathrm{Z}_{\text {eu }}$ and $\mathrm{Z}_{\mathrm{Ic}}$.

229 2.2. Nutrient and chlorophyll measurements

230 Seawater for nutrient assays was collected from the Niskin bottles attached

231 to the CTD/Rosette system into acid cleaned $(10 \% \mathrm{HCl})$, 'aged' by multiple water

232 rinsing and soaking cycles, $60 \mathrm{ml}$ HDPE (Nalgene) sample bottles. In most cases,

233 samples were analysed immediately for nutrients, and always within 2-3 hours of

234 collection. The micromolar nutrient analysis was carried out using a Bran and

235 Luebbe 5-channel (nitrate, nitrite, phosphate, silicate, ammonium) AAIII segmented

236 flow, colorimetric, autoanalyser, using classical proven analytical techniques

237 (Woodward and Rees, 2001). Micromolar detection limits for nitrate, nitrite, and

238 phosphate were $0.2 \mu \mathrm{mol} \mathrm{l}^{-1}$, and for ammonium was $0.5 \mu \mathrm{mol} \mathrm{l}^{-1}$. The concentration

239 of silicate was always within the detection limit of the analyser. The accuracy of the

240 measurements was $1-2 \%$.

241 Nanomolar ammonium was analysed using a method based on the gas

242 diffusion of ammonia across a Teflon membrane driven by a differential $p \mathrm{H}$

243 gradient, and detection by a Jasco fluorometer (adaptation of Jones (1991))

244 following its reaction with a fluorescent reagent. Nanomolar nitrate, nitrite, and

245 phosphate were detected using colorimetric methodologies as with the standard

246 segmented flow analyser, but using $2 \mathrm{~m}$ long Liquid waveguides capillary cells as the

247 analytical flow cells; the detection limits for nanomolar nitrate and phosphate were

$2481 \mathrm{nmol} \mathrm{l}^{-1}$, and for nitrite was $0.5 \mathrm{nmol} \mathrm{l}^{-1}$. The nitracline was defined as the

249 sampling depth in the upper $150 \mathrm{~m}$ of the water column at which the nitrate

250 concentration gradient was the steepest. The depth of the $300 \mathrm{nmol}$ nitrate $\mathrm{l}^{-1}$

251 isopleth was obtained from individual nutrient profiles through linear interpolation.

252 Clean handling techniques were employed to avoid any contamination of the

253 samples, particularly for the ammonium samples. Dura-Touch gloves were used at

254 all times and samples were not decanted or transferred, but were kept tightly closed

255 until just before ammonium analysis in order to avoid any contamination from

256 external sources. No water column nutrient samples were frozen or stored. All 
sampling and handling techniques, whenever possible, followed the international 258 nutrient GO-SHIP manual (Hydes et al., 2010).

259 Discrete Chla samples were measured fluorometrically (Holm-Hansen and 260 Riemann, 1978) at 6 depths spanning the surface, the bottom of the euphotic zone, 261 and the mixed layer and Chla maximum depths. Up to $4 \mathrm{l}$ of seawater, retrieved 262 directly from the Niskin bottles or the surface seawater inflow, were sequentially 263 filtered through a $20 \mu \mathrm{m}$ pore-size polycarbonate filter, a $2 \mu \mathrm{m}$ pore-size 264 polycarbonate filter, and a $0.3 \mu \mathrm{m}$ pore-size glass fiber filter (GF-75; Sterlitech; 47 $265 \mathrm{~mm}$ diameter). Filtrations were performed in the dark under low vacuum $(<200$ 266 mbar). The Chla filters were packaged into aluminium foil (GF filter) or a $5 \mathrm{ml}$

267 cryovial (polycarbonate filters) and immediately frozen at $-80{ }^{\circ} \mathrm{C}$ until analysis.

268 Chlorophyll was extracted in $90 \%$ acetone at $4^{\circ} \mathrm{C}$ overnight and measured using a

269 Turner Trilogy fluorometer, calibrated against a pure Chla standard (Anacystis 270 nidulans Chla, Sigma-Aldrich, Saint-Louis, USA). Measurements were corrected for 271 the fluorescence of phaeopigments after acidification with $\mathrm{HCl}(24 \mathrm{mM}$ final 272 concentration). Depth-integrated Chla was calculated using the fluorometric 273 measurements from the CTD casts (Fluo), which were rescaled according to the 274 relationship between $\log _{10}$ [Chla] and $\log _{10}$ [Fluo] $\left(\log _{10}\right.$ [Chla] $\left(\mathrm{ng} \mathrm{l}^{-1}\right)=0.74 \times$ $275 \log _{10}$ [Fluo] $+2.52 ; r^{2}=0.74, \mathrm{p}<0.001, \mathrm{df}=95$ ) and checked for the absence of 276 systematic residual errors. The proportion of Chla in each biomass size fraction 277 along the depth profile was linearly interpolated using the point measurements of 278 size-fractionated Chla. Depth-integrated Chla in each size fraction was calculated by 279 trapezoidally integrating the rescaled [Fluo] over the water column to $Z_{\text {Ic }}$ or the 280 MLD, whichever was deepest.

\section{$281 \quad$ 2.3. Nitrogen isotope measurements}

282 Water column nitrate+nitrite: Seawater samples for analysis of the N isotopic 283 composition of nitrate+nitrite and nitrate-only were collected unfiltered at regular 284 depth intervals from the surface to $1000 \mathrm{~m}$ in $60 \mathrm{ml}(>150 \mathrm{~m})$ or $125 \mathrm{ml}(<150 \mathrm{~m})$ 285 square-bottomed, wide-mouth HDPE bottles (Nalgene). Bottles were acid-washed 286 and rinsed with deionised water prior to sampling. At sea, pre-labelled bottles and 
287 caps were rinsed three times with sample water, filled to $\sim 85 \%$ of the bottle 288 volume, and frozen upright at $-20^{\circ} \mathrm{C}$ until analysis.

289 Isotopic analyses were conducted using the "denitrifier method", wherein 290 denitrifying bacteria lacking nitrous oxide $\left(\mathrm{N}_{2} \mathrm{O}\right)$ reductase quantitatively convert 291 nitrate and nitrite in the sample to $\mathrm{N}_{2} \mathrm{O}$ gas (Casciotti et al., 2002; Sigman et al., 292 2001) (see also Weigand et al. (2016)) for the updated protocol used for analysing 293 these samples). The isotopic composition of $\mathrm{N}_{2} \mathrm{O}$ was then measured by gas 294 chromatography-isotope ratio mass spectrometry (GC-IRMS) using a purpose-built 295 on-line $\mathrm{N}_{2} \mathrm{O}$ extraction and purification system and a Thermo MAT 253 mass 296 spectrometer. Seawater solutions of the international nitrate reference materials, 297 IAEA-N3 and USGS-34, as well as an in-house $\mathrm{N}_{2} \mathrm{O}$ standard, were run in parallel 298 with the samples in order to monitor the quality of bacterial $\mathrm{N}$ conversion and mass 299 spectrometric measurements. The reference materials bracketed each group of $\sim 10$ 300 samples and were used to correct the measured $\delta^{15} \mathrm{~N}$ to $\mathrm{N}_{2}$ in air (Casciotti et al., 301 2002; McIlvin and Casciotti, 2011; Sigman et al., 2001). Data are reported here only 302 for samples with nitrate+nitrite concentrations $\geq 300 \mathrm{nmol} \mathrm{l}^{-1}$.

303 The presence of nitrite, even at very low concentrations, can significantly 304 alter the isotopic composition of nitrate+nitrite relative to that of nitrate alone 305 (Fawcett et al., 2015; Granger and Sigman, 2009; Marconi et al., 2015; Smart et al., 306 2015). In this study, we used the $\delta^{15} \mathrm{~N}$ of nitrate-only to avoid interference from the 307 isotopic composition of nitrite, which originates from the first step of nitrification or

308 is excreted by phytoplankton following intracellular nitrate reduction to nitrite 309 (Lomas and Lipschultz, 2006); it thus does not contribute to new production sensu 310 strictu. The mean difference between the $\delta^{15} \mathrm{~N}$ of nitrate+nitrite and the $\delta^{15} \mathrm{~N}$ of 311 nitrate-only in the upper $150 \mathrm{~m}$ was $\sim 1 \%$, and this was mostly dependent on the 312 relative contribution of nitrite to the combined nitrate+nitrite pool ( $6 \%$ on average). 313 However, the nitrite concentration was significant at times, and the greatest $\delta^{15} \mathrm{~N}$ 314 difference $(\sim 4.8 \%)$ was observed where the contribution of nitrite to the 315 nitrate+nitrite pool was highest ( $32 \%$ at $\sim 60^{\circ} \mathrm{W}$; station 5 at $\left.60 \mathrm{~m}\right)$. 
In order to measure the $\delta^{15} \mathrm{~N}$ of nitrate-only for samples with a detectable 317 concentration of nitrite, a nitrite removal pre-treatment is required. The detection 318 limit for nitrite in this case was $2 \mathrm{nmol} \mathrm{kg}^{-1}$. Samples collected between the surface 319 and $\sim 125 \mathrm{~m}$ were treated for nitrite removal via the addition of $10 \mu \mathrm{l}$ of sulphamic 320 acid solution per $\mathrm{ml}$ of sample, which converts sample nitrite to $\mathrm{N}_{2}$ gas with a 321 reaction time of 2-8 minutes, followed by the addition of $5.5 \mu \mathrm{l}$ of $2 \mathrm{M} \mathrm{NaOH}$ per ml of 322 sample to restore the $p \mathrm{H}$ of the sample to $\sim 7-9$ (Granger and Sigman, 2009). The 323 pooled standard error for $\delta^{15} \mathrm{~N}$ was $0.04 \%$ and $0.11 \% 0(\mathrm{n} \geq 3)$ for nitrate+nitrite 324 and nitrate concentrations $\geq 0.5 \mu \mathrm{mol} \mathrm{l}^{-1}$ and $<0.5 \mu \mathrm{mol} \mathrm{l}^{-1}$, respectively. Hereafter, 325 "nitrate" in the text refers to nitrate-only, after the subtraction (for concentration) 326 or removal (for $\delta^{15} \mathrm{~N}$ ) of nitrite.

$327 \quad$ Suspended particulate N: Suspended PN was collected at various depths 328 throughout the euphotic zone, including within the surface mixed layer and the 329 depth of maximum Chla concentration, by gentle vacuum filtration ( $<135 \mathrm{mbar}$ ), of $3308 \mathrm{l}$ of seawater through a GF-75 filter. Filters were transferred to pre-combusted $331\left(500^{\circ} \mathrm{C}\right.$ for $\left.5 \mathrm{~h}\right)$ aluminium foil envelopes, and immediately frozen at $-80^{\circ} \mathrm{C}$ until 332 analysis.

333 In the laboratory, the PN filters were dried in a desiccating oven at $40^{\circ} \mathrm{C}$. 334 Three subsamples were cored from each filter and transferred to combusted $4 \mathrm{~mL}$ 335 glass Wheaton vials. PN was oxidised to nitrate using the persulphate oxidation 336 method of Knapp et al. (2005), and as modified by Fawcett et al. (2011; 2014); this 337 was conducted in a laminar flow hood equipped with an ammonia/amine filter. 338 Briefly, $2 \mathrm{ml}$ of persulphate oxidising reagent (POR) were added to each sample vial, 339 as well as to triplicate vials containing a filter blank plus varying quantities of two L340 glutamic acid isotope standards, USGS-40 and USGS-41 (Qi et al., 2003); this allows

341 determination of the $\mathrm{N}$ content and $\delta^{15} \mathrm{~N}$ of the POR+filter blank. The POR was made 342 by dissolving $2.5 \mathrm{~g}$ of $4 \times$ recrystallised, methanol-rinsed potassium persulphate and $3432.5 \mathrm{~g}$ of sodium hydroxide in $100 \mathrm{ml}$ of ultra high-purity deionised water. Following 344 POR addition, vials were autoclaved at $121^{\circ} \mathrm{C}$ for 55 minutes on a slow-vent setting, 345 after which sample $p \mathrm{H}$ was lowered to 6-8 using $12 \mathrm{~N} \mathrm{HCl}$. The concentration and 
$346 \delta^{15} \mathrm{~N}$ of the resultant nitrate was measured via chemiluminescent analysis (Braman 347 and Hendrix, 1989) and the denitrifier method (see above) (Casciotti et al., 2002;

348 Sigman et al., 2001). The final $\mathrm{N}$ content and $\delta^{15} \mathrm{~N}$ of the oxidised samples was

349 corrected for the POR+filter blank. N content was converted to PN concentration by 350 normalising to whole-filter area and volume of seawater filtered. For each station, 351 upper ocean average $\delta^{15} \mathrm{~N}-\mathrm{PN}$ was calculated by trapezoidally integrating the PN 352 concentration from the surface to the nitracline depth or the MLD, whichever was 353 deepest, and then weighting the individual measurements of $\delta^{15} \mathrm{~N}-\mathrm{PN}$ by the depth354 integrated PN concentration for each depth interval. In order to compare upper 355 ocean $\delta^{15} \mathrm{~N}-\mathrm{PN}$ across the transect without the confounding effect of the variable 356 source nitrate $\delta^{15} \mathrm{~N}$, the measured $\delta^{15} \mathrm{~N}$ of nitrate at $250 \mathrm{~m}$ or $300 \mathrm{~m}$ at each station 357 was subtracted from the mass-weighted average $\delta^{15} \mathrm{~N}-\mathrm{PN}$. Station 7 (bottom depth 358 of $57 \mathrm{~m}$ ) was excluded from these calculations due to the uncertainty of the $\delta^{15} \mathrm{~N}$ of 359 its nitrate source and the potential impact of sedimentary processes on $\delta^{15} \mathrm{~N}-\mathrm{PN}$.

360 2.4. Plankton abundance and biomass determination

361 The cell abundance of pico- and nanophytoplankton $(<\sim 14 \mu \mathrm{m}$ cell diameter $)$ 362 was determined by flow cytometric analysis of $1500 \mu \mathrm{l}$ of glutaraldehyde-preserved $363(1 \% \mathrm{v} / \mathrm{v})$ (Marie et al., 1997) samples using a BD Accuri C6 flow cytometer equipped 364 with a blue laser ( $488 \mathrm{~nm}$ ), at a flow rate of $100 \mu \mathrm{min}^{-1}$, and a core diameter of 22 $365 \mu \mathrm{m}$. Standard fluorescent bead solutions were prepared daily and used as an 366 internal standard to assess instrument performance, to standardise scatter and 367 fluorescence measurements (Rainbow Calibration Particles (8 peaks), BD 368 Biosciences), and to validate the flow rate (TruCount, BD Biosciences) for 369 quantitative applications. Each sample was run with fluorescent beads (YG beads, $3700.94 \mu \mathrm{m}$ Fluoresbrite ${ }^{\circledR}$ Yellow Green Microspheres, Polysciences, Inc.) as an internal 371 standard for forward scatter measurements.

372 Several phytoplankton groups were distinguished based on their forward 373 (FSC) and side scatter (SSC), Chla, and phycoerythrin (PE) fluorescence signals 374 (Table 2): the picophytoplankton $(<\sim 2.5 \mu \mathrm{m})$ group comprised PE-containing 375 Synechococcus and non-PE-containing picoeukaryotes (picoEuks), the 
376 nanophytoplankton groups (nanoEuks, > 2.5 - $14 \mu \mathrm{m}$ ) included PE-containing 377 nanophytoplankton (PE-nanoEuk), non-PE-containing phytoplankton (noPE378 nanoEuk), and coccolithophores (Cocco) (the latter group was identified based on 379 their enhanced side scatter signal). Representative flow cytometry density plots 380 from which the phytoplankton populations were identified are shown in Figure S1. 381 The picoplanktonic Prochlorococcus cells were counted in SYBR Green I382 stained samples (Marie et al., 1997), according to (Heywood et al., 2006), because of 383 the difficulty of discriminating unstained cells from background noise. The 384 concentration of heterotrophic bacterial cells was determined by flow cytometric 385 analysis of $250 \mu \mathrm{l}$ of glutaraldehyde-preserved (1\% v/v) and SYBR Green I-stained 386 (1:7500) samples according to Marie et al. (1997) and Gasol and Del Giorgio (2000). 387 The Prochlorococcus and heterotrophic bacteria samples were analyzed using a BD 388 Accuri C6 flow cytometer, at a flow rate of $35 \mu \mathrm{min}^{-1}$, and a core diameter of $16 \mu \mathrm{m}$. 389 All plankton groups were gated and their abundance quantified using FlowJo 390 software (Tree Star, Inc., www.flowjo.com).

391 The biovolume of phytoplankton cells analysed by flow cytometry was 392 derived from forward scatter measurements of individual cells based on the 393 polynomial relationship between the $\log _{10}$ of measured biovolumes of pico- and 394 nanophytoplankton cells and the $\log _{10}$ of the peak area of their forward scatter 395 signal (FSC-A) (Laney and Sosik, 2014). A calibration procedure, using bead stocks 396 and an unidentified cultured picoeukaryote from the Sosik Lab at Woods Hole 397 Oceanographic Institution, confirmed the inter-lab agreement of flow cytometry398 derived biovolume estimates (Figure S2). Since the largest phytoplankton cell in the 399 empirical relationship of Laney \& Sosik (2014) had a cell diameter of $14 \mu \mathrm{m}$ and the 400 number of cells larger than this in our samples was negligable, only cells up to $\sim 14$ $401 \mu \mathrm{m}$ in diameter were included in the cell abundance and biovolume calculations. 402 Cellular biomass was estimated according to the relationship between cellular 403 biovolume $\left(\mu \mathrm{m}^{3}\right.$ cell-1) and carbon content (pmol cell-1) for glutaraldehyde 404 preserved pico- and nanophytoplankton cells from (Verity et al., 1992): C = (0.433 / 405 12) $\times$ biovolume ${ }^{0.863}$. 
Although Synechococcus cells could readily be counted based on their size and their characteristic PE fluorescence, the high signal-to-noise ratio in the FSC-A 408 channel of the Accuri precluded a reliable cell size estimate for particles smaller 409 than $1 \mu \mathrm{m}$. Therefore, the biomass of Synechococcus was estimated using a 410 conversion factor of $140 \mathrm{fg} \mathrm{C}^{-1}$ cell $^{-1}$ assuming a cell diameter of $1 \mu \mathrm{m}$ and $270 \mathrm{fg} \mathrm{C}$ $411 \mu^{-3}$ (Bertilsson et al., 2003). The biomass of Prochlorococcus cells was calculated by 412 using an average cellular carbon content of $53.5 \mathrm{fg} \mathrm{C}^{-1}$ cell-1 $^{-1}$ (Bertilsson et al., 2003), 413 which is very similar to the range of cellular carbon content determined by Casey et 414 al. (2013) for Prochlorococcus in the euphotic zone.

\section{2.5. Primary productivity}

416 Primary production rates were determined with the ${ }^{13} \mathrm{C}$-uptake technique 417 using on-deck, running surface seawater-cooled incubations, which simulated the in 418 situ irradiance conditions at three depths corresponding to 55\%,33\%, and $1 \%$ of 419 surface PAR. The incubations were started at dawn by adding $1.40 \mathrm{ml}$ of a freshly 420 prepared ${ }^{13} \mathrm{C}$-labelled (99\%) bicarbonate solution (for a final concentration of 200 $421 \mu \mathrm{mol}{ }^{13} \mathrm{C} \mathrm{l}^{-1}$ ) to each light-shielded, mesh-wrapped polycarbonate incubation bottle, 422 and lasted for $6.5 \pm 0.2 \mathrm{~h}$. The entire content ( $2300 \mathrm{ml})$ of each incubation bottle was 423 then filtered through a combusted $\left(450^{\circ} \mathrm{C}\right.$ for 5 hours) GF-75 filter and frozen at $42480^{\circ} \mathrm{C}$ until analysis on land. In the laboratory, frozen GF-75 filters were thawed and 425 fumed with concentrated $\mathrm{HCl}$ for $6 \mathrm{~h}$ to remove inorganic carbon, after which they 426 were dried in a desiccating oven at $60^{\circ} \mathrm{C}$ for at least $24 \mathrm{~h}$. The rim and two sections 427 of each filter were cut out, placed in tin capsules, pelletised, and analysed on a 428 Europa Scientific 20/20 triple collector mass spectrometer. Measurements of 429 particulate organic carbon (POC) mass and isotopic composition were corrected for 430 the blank, which consisted of a tin capsule and a blank pre-combusted GF-75 431 section. Daily standard curves bracketing anticipated sample masses were run prior 432 to samples, with urea as a laboratory standard, and the measured isotopic 433 composition was calibrated using peach leaf (NIST-1547) and L-glutamic acid 434 (USGS-40; (Qi et al., 2003)) standards. Using the daily standard curves, the mass of 435 POC in each sample was calculated. The hourly rate of photosynthetic carbon 
436 fixation by the phytoplankton community was determined from duplicate 437 incubation samples by normalising the rate of dissolved inorganic carbon (DIC) 438 incorporation into POC to the length of the incubation, calculated following 439 (Legendre and Gosselin, 1997). These hourly rates of photosynthetic carbon fixation 440 were then adjusted to account for the deviation of surface seawater incubation 441 temperature from in situ temperature using a $\mathrm{Q}_{10}$ temperature coefficient for 442 growth of 1.88 (Bissinger et al., 2008; Eppley, 1972).

\section{$443 \quad$ 2.6. Data analysis and mapping}

444 The arithmetic mean of the data is reported \pm the standard deviation from

445 the mean, or as a range of minimum to maximum values. CTD measurements were 446 binned over $1 \mathrm{~m}$ depth intervals. Linear correlation between two sets of 447 measurements was calculated via Pearson's coefficient using the pearsonr function 448 from the SciPy 0.16 .1 statistical functions module, and the least-squares regression 449 for two sets of measurements was computed using the linregress function from the 450 SciPy statistical functions module (SciPy 0.16.1, www.scipy.org). The Data451 Interpolating Variational Analysis (DIVA) gridding option in Ocean Data View 452 (ODV4) was used to interpolate the biological, physical, and chemical data in space 453 (Schlitzer, 2015; Troupin et al., 2012). In section plots showing the relative 454 abundance of phytoplankton groups, data points below the light compensation 455 depth, where an insufficient number of observations in a particular population 456 ( $\mathrm{n}<250)$ were made due to insufficient sampling effort for the given population size, 457 were removed. Since the data shown are ratios of a particular population to the sum 458 of all populations, an insufficient number of observations in one population could 459 have skewed the ratio estimate of individual populations.

\section{3. Results}

\section{3.1. Overview of the transect hydrography and biogeochemistry}

462 The transect cruise across the North Atlantic Ocean began on August 23rd, 4632013 from the coast of North Carolina (USA) along the Gulf Stream, crossed the 
464 Grand Banks, proceeded along the North Atlantic Current, and ended in the 465 northeast $\left(54^{\circ} \mathrm{N} 20^{\circ} \mathrm{W}\right)$ at the southern border of the subarctic Atlantic province 466 (Figure 1 and Figure S3). The southwestern section of the transect followed the 467 warm, saline waters of the Gulf Stream to the west of the Grand Banks ( $\left.\sim 44^{\circ} \mathrm{W}\right)$. 468 There, the west-to-east flowing Gulf Stream extends as the North Atlantic Current at $46940^{\circ} \mathrm{W}$, and is directed to the eastern Atlantic basin through the transverse Charlie470 Gibbs Fracture Zone (Bower and von Appen, 2008; García-Ibáñez et al., 2015). The 471 transect was characterised by zonal and meridional gradients in temperature, 472 salinity, nutrient and PN concentrations, $\mathrm{N}$ isotopic composition of nitrate and PN, 473 and phytoplankton biomass. Using these gradients we operationally grouped the 474 stations into the southwestern stations (2-6), the shelf station (7), and the 475 northeastern stations (8-15) (Table 1).

476 Sea surface temperature (SST) decreased zonally from $29.0^{\circ} \mathrm{C}$ at station 2 in 477 the Gulf Stream to $13.8^{\circ} \mathrm{C}$ at station 15 at the border of the Atlantic subarctic 478 province, just west of Rockall Bank (Figure 2A). Surface salinity decreased 479 significantly from a maximum of 36.02 psu at station 4 , to 32.50 psu at station 7 at 480 the tip of the Grand Banks shelf, and rose again to a maximum of 35.38 psu at station 48111 further northeast (Figure 2B). Nutrient concentrations were depleted in at least 482 the upper $30 \mathrm{~m}$ of the water column throughout most of the transect (nitrate $<100$ 483 nmol l-1, nitrite $<20 \mathrm{nmol} \mathrm{l}^{-1}$, ammonium $<50 \mathrm{nmol} \mathrm{l}^{-1}$, phosphate $<100 \mathrm{nmol} \mathrm{l}^{-1}$; 484 Figure 2C and Figure S4). At the northeastern stations, however, only silicate 485 concentrations were low (332 - $779 \mathrm{nmol} \mathrm{l}^{-1}$ ), while at the southwestern stations, 486 maximum silicate concentrations ranged between 859 and $1856 \mathrm{nmol} \mathrm{l}^{-1}$ (Figure 487 S4D). The depth of the nitracline shoaled from the southwest (max. $=101 \mathrm{~m}$, station 4883 ) to the northeast ( $\mathrm{min} .=33 \mathrm{~m}$ ), where nitrate was at least $451 \mathrm{nmol} \mathrm{l}^{-1}$ in surface 489 waters of the northeastern stations $(12,13,15)$ (Figure 2C and Table 1). The depth 490 of the nitracline was correlated with $Z_{\text {Ic }}$ but not with MLD (Table 3). Nitrite maxima 491 were typically observed between the nitracline and $Z_{\text {Ic }}$ (except at the northeastern492 most station 15, where the nitrite maximum was situated just below $\mathrm{Z}_{\text {Ic }}$ ). Nitrite 493 maxima ranged from 51 to $158 \mathrm{nmol} \mathrm{l}^{-1}$ at the southwestern stations, $42 \mathrm{nmol} \mathrm{l}^{-1}$ 
494 near the bottom of the shelf station, and from 69 to $485 \mathrm{nmol} \mathrm{l}^{-1}$ at the northeastern 495 stations (Figure S4A).

496 The distribution of upper ocean PN mirrored the distribution of nitrate, with

497 the highest concentrations at each station observed at or just below the nitracline in 498 the southwest or in the upper mixed layer of the northeastern stations (Figure 2C 499 and Figure 3A). The concentration of PN above $Z_{\text {eu }}$ ranged from 0.28 to $1.04 \mu \mathrm{mol} \mathrm{l}^{-1}$ 500 at the southwestern stations and from 0.40 to $2.35 \mu \mathrm{mol} \mathrm{l}^{-1}$ at the northeastern 501 stations. Occasional localised PN peaks (e.g., $3.97 \mu \mathrm{mol} \mathrm{l}^{-1}$ at $30 \mathrm{~m}$ at station 7 on the

502 Grand Banks shelf and $2.18 \mu \mathrm{mol} \mathrm{l}^{-1}$ at $45 \mathrm{~m}$ at station 8) were observed, and these 503 corresponded with occurrences of high phytoplankton biomass detected by flow 504 cytometry (see section 2.4). The distribution of POC was strongly correlated with

505 that of PN (Table 3) and the POC-to-PN molar ratio of suspended particles 506 throughout the euphotic zone had an average value of $7.3 \pm 2.8$ ( $n=33)$, which did 507 not show a trend with longitude or latitude $(r<0.02, p>0.1)$.

508 3.2. Nitrogen isotopic composition of $\mathrm{PN}$ and nitrate

509 Vertical patterns in the $\delta^{15} \mathrm{~N}$ of nitrate and suspended PN provide a time510 integrated view of the dynamics of new production - according to the classical 511 paradigm - at each station (Figure 4). At depths shallower than the $300 \mathrm{nmol} \mathrm{l}^{-1}$ 512 nitrate isopleth, the nitrate concentration was too low for $\delta^{15} \mathrm{~N}$ determination. For 513 all profiles, the $\delta^{15} \mathrm{~N}$ of nitrate was highest at the shallowest depth for which nitrate 514 was greater than our $\delta^{15} \mathrm{~N}$ quantification threshold, and was slightly higher at the 515 northeastern stations (average of 9.4\%0), compared to the southwest (average of $5168.5 \%$ ) (Figure 4B). Evidence for nitrate assimilation, implied by the elevated $\delta^{15} \mathrm{~N}$ of 517 shallow nitrate compared to its subsurface source, was observed deeper in the 518 water column to the southwest compared to the northeast (Figure 4B). The 519 relatively low $\delta^{15} \mathrm{~N}$ of the source nitrate (below the main thermocline and $\mathrm{Z}_{\text {Ic }}$ ) in the 520 southwestern section of the transect ( $2.5 \pm 0.1 \%$ at $250 \mathrm{~m}$, stations $2,3,4$ and 5 ) 521 compared to the source nitrate in the northeastern section $(4.7 \pm 0.2 \%$ o between 522200 and $300 \mathrm{~m}$ ) points to different origins for this nitrate. 
523 The $\delta^{15} \mathrm{~N}$ of PN increased from the southwest $(-0.4 \pm 0.4 \%$ at $20 \mathrm{~m}, \mathrm{n}=5 ; 0.3$

$524 \pm 1.1 \%$ o for all samples above the nitracline, $n=9$; stations $2-6)$ to the northeast (4.2

$525 \pm 0.2 \%$ above the nitracline; stations $11,12,13$ and $15, \mathrm{n}=7$ ) (Figure 4A). The mass-

526 weighted upper ocean average $\delta^{15} \mathrm{~N}$ of PN decreased with increasing depth of the

527 nitracline and the difference between the $\delta^{15} \mathrm{~N}$ of PN and source nitrate was less to

528 the northeast, indicating higher nitrate reliance (Table 3; excluding shelf station 7).

529 In general, the $\delta^{15} \mathrm{~N}$ of PN increased with depth from the shallowest sample to the 530 waters at or below the nitracline.

\section{$531 \quad 3.3$. Phytoplankton chlorophyll $a$ biomass and community size-structure}

532 Surface Chla concentrations were low $\left(<0.5 \mathrm{mg} \mathrm{m}^{-3}\right)$ across most of the 533 transect but increased sharply at the northeastern end (Figure 5A). The depth of the 534 Chla maximum at each station shoaled from the southwest to the northeast, 535 essentially following the depth of the nitracline. The depth-integrated chlorophyll 536 ( $\Sigma$ Chla), integrated from the surface to the light compensation depth $\left(\mathrm{Z}_{\mathrm{Ic}}\right)$, was also 537 higher at the northeastern stations 13 and $15\left(33.6 \mathrm{mg} \mathrm{m}^{-2}\right.$ and $30.4 \mathrm{mg} \mathrm{m}^{-2}$, 538 respectively) compared to the transect average (19.1 $\pm 7.2 \mathrm{mg} \mathrm{m}^{-2}, \mathrm{n}=12$ ) (Figure 6). 539 The degree to which these patterns in Chla distribution were representative of the 540 average conditions during late summer was assessed by comparing in situ Chla 541 measurements to the distribution of climatological remote sensing data for each 542 station (Figure S5). The median [Chla] above $\mathrm{Z}_{\mathrm{Ic}}$ was below average (i.e., the 543 median) for the southwestern stations and stations 7 and 8, near average for 544 stations 9 to 12, and above average for the two northeastern-most stations 13 and 545 15. The higher-than-expected [Chla] at the two northeastern-most stations is thus 546 indicative of summer bloom conditions.

$547 \quad$ Throughout the transect, most of the $\Sigma$ Chla was contained in the pico $(<2$ $548 \mu \mathrm{m})(78 \pm 13 \%, \mathrm{n}=12)$ and nano sized-fractions $(2-20 \mu \mathrm{m})(20 \pm 11 \%, \mathrm{n}=12)$. The 549 proportion of Chla in the micro sized-fraction ( $>20 \mu \mathrm{m})$ was very low on average (3 $550 \pm 2 \%, \mathrm{n}=12$ ) (Figure 6). The northeastern stations (12, 13 and 15), together with the 551 shelf station 7 , were characterised by the highest contribution of 
552 nanophytoplankton (up to $36 \%$ at station 13) and microphytoplankton (up to $8 \%$ at 553 station 7) to $\Sigma$ Chla.

\section{3.4. Pico- and nanoplankton abundance and biomass}

555 The abundance and biomass of pico- and nanoplankton were determined by

556 flow cytometry in order to produce a more detailed description of phytoplankton

557 community diversity and to assess the biomass distribution of each phytoplankton

558 group, avoiding the confounding effect of light intensity that complicates

559 interpretation of the complementary size-fractionated Chla measurements. At the

560 southwestern stations, Prochlorococcus cells numerically dominated the

561 phytoplankton community yet Prochlorococcus was not detected at the shelf and

562 northeastern stations (Figure S6A). Maximum cell concentrations at the

563 southwestern stations were observed deep in the euphotic zone, above or just

564 below the nitracline $\left(0.86-1.24 \times 10^{6} \mathrm{cells} \mathrm{ml}^{-1}\right)$, as well as in the upper $20 \mathrm{~m}$ of the

565 water column at stations 5 and $6\left(0.86-1.44 \times 10^{5}\right.$ cells ml-1). Synechococcus was

566 present throughout the transect although cell concentrations were low in the

567 southwestern section, increasing towards the northeast. At the southwestern

568 stations the highest abundance of this group was mostly confined to the upper $20 \mathrm{~m}$

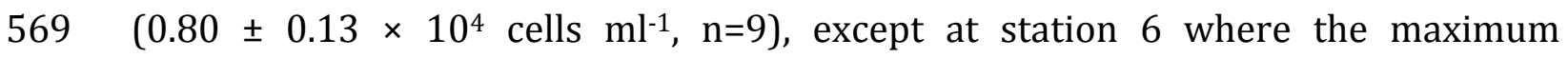

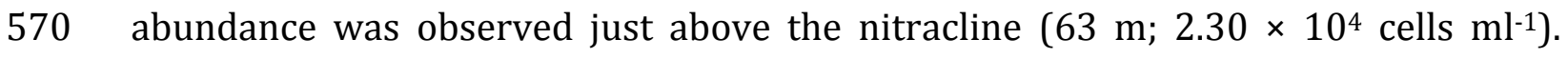

571 Synechococcus cells were most abundant in the nitracline at the shelf station 7 and

572 station 8, and at the surface of the northeastern station $13\left(5.32-7.19 \times 10^{4}\right.$ cells $^{-}$

573 1) (Figure S6B). The abundance of picoeukaryotes and nanoeukaryotes was lower in

574 the southwestern part of the transect, with maxima at or below the nitracline

575 (picoEuks: $4.4 \pm 2.3 \times 10^{3}$ cells ml-1 ${ }^{-1}$, nanoEuks: $0.6 \pm 0.3 \times 10^{3}$ cells ml $^{-1}$ ), compared

576 to the shelf and the northeastern stations (picoEuks: $9.8 \pm 6.7 \times 10^{3}$ cells ml- $^{-1}$;

577 nanoEuks: $3.1 \pm 1.6 \times 10^{3}$ cells $\mathrm{ml}^{-1}$ ) (Figures $\mathrm{S} 6 \mathrm{C}$ and $\mathrm{S6D}$ ). In the

578 nanophytoplankton size group, the noPE-nanoEuk population was by far the most

579 numerically abundant group ( $94 \pm 6 \%$ of total nanophytoplankton cells). The cell

580 abundance of the other nanophytoplankton groups, Cocco and PE-nanoEuk, was

581 very low across the entire transect $\left(<0.1 \times 10^{3}\right.$ cells ml $^{-1},<0.4 \times 10^{3}$ cells ml$\left.^{-1}\right)$, 
582 although PE-nanoEuk cells constituted up to $20 \%$ of all nanophytoplankton cells at 583 station 6 (data not shown).

584 Because of large differences in cell size, the total biomass distribution of 585 populations determined from biovolume estimates (Figures $5 \mathrm{~B}$ and 7 ) is distinct 586 from the patterns of Chla and cell abundance outlined above (Figures 6A and S6). 587 Prochlorococcus contributed up to $0.47 \pm 0.12 \mu \mathrm{mol} \mathrm{C} \mathrm{l}^{-1}$ or $46 \pm 7 \%(\mathrm{n}=5)$ of the 588 combined pico- and nanophytoplankton carbon biomass at their depth maxima at 589 the southwestern stations (Figures $7 \mathrm{~A}$ and $8 \mathrm{~A}$ ). The biomass concentrations of 590 Synechococcus and picoeukaryotes were of the same order of magnitude (Figures 7B 591 and $7 \mathrm{C}$ ), with maxima ranging from 0.10 to $0.27 \mu \mathrm{mol} \mathrm{C}^{-1}$ and 0.16 to $0.42 \mu \mathrm{mol} \mathrm{C} \mathrm{l}^{-1}$ 592 at the southwestern stations, and from 0.15 to $0.85 \mu \mathrm{mol} \mathrm{C} \mathrm{l}^{-1}$ and 0.21 to $1.04 \mu \mathrm{mol}$ $593 \mathrm{C} \mathrm{I}^{-1}$ at the shelf and northeastern stations. Nanoeukaryote biomass at the 594 southwestern stations was lower than at the shelf and northeastern stations. At 595 their depth maxima, nanoeukaryotes biomass ranged from 0.32 to $0.84 \mu \mathrm{mol} \mathrm{C} \mathrm{l}^{-1}$ in 596 the southwest, from 1.04 to $5.33 \mu \mathrm{mol} \mathrm{C}^{-1}$ in the northeast, and had a localised peak 597 of $8.63 \mu \mathrm{mol} \mathrm{C} \mathrm{l}^{-1}$ at the shelf station ( $30 \mathrm{~m}$ ) (Figure 7D). Cyanobacteria dominanted 598 the picophytoplankton biomass in the southwestern section (76 $\pm 14 \%, n=27)$ 599 compared to the northeastern stations $(37 \pm 20 \%, \mathrm{n}=38)$ in the upper $125 \mathrm{~m}$ of the 600 water column (Figures 8A and 8B).

601 The vertical distribution of picophytoplankton biomass showed group602 specific trends. The picoeukaryote populations made up a relatively greater 603 proportion of the pico- and nanophytoplankton biomass $(17.0 \pm 7.9 \%, n=20)$ at the 604 depths near the nitracline (when present) compared to Synechococcus $(9.2 \pm 7.7 \%$, $605 \mathrm{n}=20$ ) (Figures 8B and 8C). Synechococcus populations, on the other hand, were 606 mostly confined to the better-lit shallower water column $(18.4 \pm 9.0 \%, n=27)$, where 607 the relative contribution of picoeukaryotes was lower $(8.9 \pm 5.0 \%, n=27$ not 608 adjacent to the nitracline).

609 The nanoeukaryote phytoplankton made up a substantial portion of the pico610 and nanophytoplankton biomass despite their relatively low cell numbers, 611 contributing $40 \pm 11 \%(\mathrm{n}=23)$ of the biomass at the southwestern stations, and $69 \pm$ $61211 \%(\mathrm{n}=39)$ at the shelf and northeastern stations in the upper $125 \mathrm{~m}$ of the water 
613 column (in instances where a representative population sample of at least 250 614 nanophytoplankton cells were counted) (Figures 8D and S6D). The distribution of

615 the nanophytoplankton biomass was heterogeneous, with low concentrations in the 616 euphotic zone in the southwestern part of the transect $\left(0.34 \pm 0.19 \mu \mathrm{mol} \mathrm{C} \mathrm{l}^{-1}, \mathrm{n}=22\right)$, 617 localised maxima at stations 7 and 8 (8.63 and $3.81 \mu \mathrm{mol} \mathrm{C} \mathrm{l}^{-1}$ ), and high 618 concentrations in the upper mixed layer of the northeastern stations 12, 13 and 15 $619\left(3.23 \pm 1.18 \mu \mathrm{mol} \mathrm{C} \mathrm{l}^{-1}, \mathrm{n}=9\right)$ (Figure 7D).

620 The average cellular carbon content for the picoeukaryotes and combined 621 nanoeukaryote phytoplankton groups was $64 \pm 16 \mathrm{fmol} \mathrm{C}$ cell-1 $^{-1}(\mathrm{n}=73)$ and $741 \pm$ $622247 \mathrm{fmol} \mathrm{C}^{\mathrm{C}}$ cell-1 $^{-1}(\mathrm{n}=68$, excluding station 7$)$, respectively, corresponding reasonably 623 well to the values reported by (Tarran et al., 2006) for picoeukaryotes (36.7 fmol C 624 cell- $\left.^{-1}\right)$ and total nanoeukaryotes $\left(763 \mathrm{fmol} \mathrm{C}^{-1 l^{-1}}\right)$ in the Northeast Atlantic in early 625 summer. Noteworthy was the larger cellular biomass of total nanoeukaryotes (1585 $626 \pm 537 \mathrm{fmol} \mathrm{C}$ cell $^{-1}, \mathrm{n}=8$ ) in the cold, low salinity waters at the shelf station 7 627 compared to the rest of the transect. The flow cytometry-derived phytoplankton 628 biomass (FCM phyto $\mathrm{C}$, $\mu$ mol $\mathrm{C} \mathrm{l}^{-1}$ ) explained $73 \%$ of the variance in POC 629 concentration $\left(\mu \mathrm{mol} \mathrm{C} \mathrm{C}^{-1}\right)$ across the transect, and the deviation from a one-to-one 630 relationship between both measures of biomass $\left(\log _{10}[\mathrm{POC}]=0.81 \times \log _{10}[\mathrm{FCM}\right.$ 631 phyto C] $+0.64, \mathrm{n}=36, \mathrm{p}<0.001$ ) points to either an underestimate of total 632 phytoplankton biomass by FCM phyto $\mathrm{C}$ or to the contribution of non-phytoplankton 633 particles, such as heterotrophs and detritus, to the POC.

634 Finally, the cell abundance of heterotrophic bacteria over the upper $125 \mathrm{~m}$ 635 ranged from $0.10-1.66 \times 10^{6}$ cells $\mathrm{ml}^{-1}$, generally decreasing with depth (Figure S7), 636 and this was positively correlated with total Chla, FCM phyto C and the rate of 637 inorganic carbon fixation ( $\rho$ DIC, $\mu \mathrm{mol} \mathrm{C} \mathrm{l}^{-1} \mathrm{~h}^{-1}$ ) (see section 3.5) (Table 3). These 638 strong correlations suggest a close coupling between the phototrophic and 639 heterotrophic components of the microbial food web.

\section{$640 \quad 3.5$. Primary production and phytoplankton turnover rate}

641 The activity of the phytoplankton standing stocks was estimated by 642 measuring the inorganic carbon fixation rate (i.e., primary production; $\rho$ DIC, $\mu$ mol C 
$\left.643 \mathrm{l}^{-1} \mathrm{~h}^{-1}\right)$ at each transect station at three irradiance levels within the euphotic zone. 644 Carbon fixation rates $(\mathrm{n}=36)$ ranged from $0.009 \mu \mathrm{mol} \mathrm{C} \mathrm{l}^{-1} \mathrm{~h}^{-1}$ at the base of the 645 euphotic zone in the oligotrophic surface waters in the southwest, to $0.132 \mu \mathrm{mol} \mathrm{C}^{-}$ $646{ }^{1} \mathrm{~h}^{-1}$ at the subsurface biomass peak in the colder Grand Bank shelf water $(30 \mathrm{~m}$, 647 station 7), and then up to $0.222 \mu \mathrm{mol} \mathrm{C}^{-1} \mathrm{~h}^{-1}$ during the summer phytoplankton 648 bloom at the northeastern-most station 15 (Figure 9A). The $\rho$ DIC showed a positive 649 relationship with the different measures of biomass: [POC], [Chla] and FCM phyto C 650 across the transect and light depths (Table 3).

651 The turnover rate of phytoplankton biomass (VDIC, $\mathrm{h}^{-1}$ ), obtained by 652 normalizing the carbon fixation rates to [FCM phyto C], ranged from 0.012 to 0.086 $653 \mathrm{~h}^{-1}$ and was generally slowest at the deepest light depth (Figure 9B). Across the 654 transect, VDIC was positively correlated with in situ temperature (Table 3). The 655 phytoplankton community composition could partly explain the variation in VDIC, 656 as it was negatively correlated with the proportion of nanophytoplankton FCM 657 carbon biomass (Table 3). However, this is likely at least partly due to the negative 658 correlation between the proportion of nanophytoplankton FCM carbon biomass and 659 in situ temperature (Table 3).

660 4. Discussion

661 4.1. Late summer hydrography and biogeochemistry in the North Atlantic

662 The zonal/meridional transect crossed several biogeographical provinces 663 (Gulf Stream (GFST), Northwest Atlantic shelves (NWCS), North Atlantic Drift 664 (NADR), and the southern border of the Atlantic subarctic province (SARC)) (Figure 665 1) (Longhurst (2007), Reygondeau et al. (2013), G. Reygondeau, personal 666 communication 2014). The broad patterns in temperature, $\mathrm{Z}_{\mathrm{eu}}$ and the horizontal 667 and vertical distribution of Chla were representative of the classical biogeographical 668 provinces described by Longhurst (2007) for the locations sampled during late 669 summer (World Ocean Atlas 2013 (WOA13), August-September; 670 https://www.nodc.noaa.gov/OC5/woa13/pubwoa13.html). A large part of the 671 southwestern section of the transect followed the Gulf Stream, which was 
672 characterised by high SST $\left(>23{ }^{\circ} \mathrm{C}\right)$. The transect stations did not intersect any 673 mesoscale eddies, as seen from the surface velocity fields (Figure S3), but the cruise 674 track did traverse sub-mesoscale fronts characterised by sharp changes in surface 675 temperature and salinity (Figure S8). At station 8, for example, the SST was $\sim 2.5-3.0$ $676{ }^{\circ} \mathrm{C}$ warmer than at adjacent $(24-39 \mathrm{~km})$ stations. The depleted surface nutrient 677 concentrations throughout the transect were typical for the late summer (nitrate 0$6782.00 \mu \mathrm{mol} \mathrm{l}^{-1}$, phosphate $0.03-0.30 \mu \mathrm{mol} \mathrm{l}^{-1}$, silicate $0.06-3.00 \mu \mathrm{mol} \mathrm{l} \mathrm{l}^{-1}$; WOA13, 679 August-September, upper $25 \mathrm{~m}$ ). The low Chla concentrations throughout the 680 transect (median [Chla]zic per station range $0.09-0.34 \mathrm{mg} \mathrm{m}^{-3}$ ) were characteristic or 681 lower-than-expected for the regions and/or the time of year (e.g., the Gulf Stream 682 and Grand Banks shelf), with the exception of the summer bloom conditions 683 observed at the two northeastern-most stations (median [Chla]zic range 0.66-0.74 $684 \mathrm{mg} \mathrm{m}^{-3}$ ) (Figure S5).

4.2. Phytoplankton community composition from the Gulf Stream to the 686 subarctic Atlantic

The biogeochemical gradients along the zonal/meridional North Atlantic 688 transect were reflected in the phytoplankton community composition. The biomass 689 and cell abundance of late summer phytoplankton communities throughout the 690 transect (GFST - SARC) were strongly dominated by pico- and nanophytoplankton 691 groups. Microphytoplankton biomass, based on size-fractionated Chla, constituted 692 only a minor part of the summer phytoplankton communities. The lack of significant 693 microphytoplankton Chla even at the northeastern summer bloom stations (Figure 694 6) may be a consequence of insufficient silicate replenishment in the case of 695 diatoms, or slow growth response time and sensitivity to increased turbulence in 696 the case of phototrophic dinogflagellates (Barton et al., 2015; Irwin et al., 2012). The 697 patterns in pico- and nanophytoplankton community size-structure and low levels 698 of biomass were consistent with the few available summer field observations for the 699 region using either flow cytometry (Buck et al., 1996; Li, 1995; Li and Harrison, 700 2001) or pigment-based approaches (Dandonneau et al., 2004). 
The maximum cell abundance of Prochlorococcus at the southwestern 702 stations in this study was comparable to that observed by flow cytometry in surface 703 waters of the western North Atlantic in August and September $\left(\sim 0.5-1 \times 10^{5} \mathrm{ml}^{-1}\right.$; 704 Casey et al. (2007); DuRand et al. (2001)), the eastern North Atlantic $\left(35^{\circ} \mathrm{N} 23^{\circ} \mathrm{W}\right)$ in 705 September $\left(\sim 1 \times 10^{5} \mathrm{ml}^{-1}\right)$ (Zinser et al., 2006) and in the Gulf Stream $\left(\sim 6 \times 10^{4} \mathrm{ml}^{-1}\right.$ 706 at $\sim 37^{\circ} \mathrm{N} \sim 69^{\circ} \mathrm{W} ; \sim 1.2 \times 10^{5} \mathrm{ml}^{-1}$ at $\sim 42^{\circ} \mathrm{N} \sim 55^{\circ} \mathrm{W}$ ) in June and September 707 (Cavender-Bares et al., 2001; Li, 1995). The lack of Prochlorococcus cells from the 708 Grand Banks $\left(\sim 44^{\circ} \mathrm{N}\right)$ northwards is consistent with its average geographical 709 distribution and preference for warmer water (at least $\sim 12{ }^{\circ} \mathrm{C}$ ) (Partensky et al., 710 1999b).

711 The detection of Synechococcus populations throughout the transect is in 712 accordance with the cosmopolitan distribution of this genus (Partensky et al., 713 1999a). Relatively higher contributions of Synechococcus to the pico- and 714 nanophytoplankton biomass were measured near the surface at the southwestern 715 stations as well as in lower salinity surface waters of the shelf and adjacent station, 716 consistent with the genus' reported niche breadth (Partensky et al., 1999a; 717 Zwirglmaier et al., 2008). Synechococcus reached its highest cell abundance at the 718 northeastern summer bloom station $13\left(7.19 \times 10^{4}\right.$ cells $\left.\mathrm{ml}^{-1}\right)$ where nitrate had 719 likely been recently resupplied. These higher cell concentrations are comparable to 720 those measured by Buck et al. (1996) and Heywood et al. (2006) during a summer 721 transect $\left(\sim 2 \times 10^{4}-1 \times 10^{5}\right.$ cells $\mathrm{ml}^{-1}$, from $\left.45^{\circ} \mathrm{N}-60^{\circ} \mathrm{N}\right)$ and may have been 722 stimulated by the higher nitrate concentrations (Glover et al., 2007; Glover et al., 723 1988) (see below).

724 Picoeukaryote phytoplankton were a ubiquitous feature of the plankton 725 community throughout the transect and, based on their biomass distribution, 726 contributed significantly to Chla in the picophytoplankton size-group, together with 727 their cyanobacterial counterparts (Figures 6, 7, and 8). This extensive geographical 728 distribution may reflect the high taxonomic diversity within this group (Grob et al., 729 2011; Kirkham et al., 2013). The exception to the ubiquitous presence of the 730 picoeukaryotes was their relative absence at the Grand Banks shelf station where 731 they were replaced by Synechococcus and nanophytoplankton. In general, 
732 picoeukaryote phytoplankton contributed relatively more to biomass deeper in the

733 water column, closer to the nitracline. Such a vertical distribution pattern seems to

734 be a consistent feature of this flow cytometrically-defined group across different

735 environments (Buck et al., 1996; Cabello et al., 2016; Painter et al., 2014; Tarran et

736 al., 2006). When nitrate was available near the surface, such as at the northeastern

737 summer bloom stations, picoeukaryote biomass was still relatively more abundant

738 closer to the base of the euphotic zone even though this group had a higher biomass

739 throughout the water column compared to the southwestern section of the transect.

740 The main trend in the distribution of nanophytoplankton was a higher

741 contribution to the total phytoplankton biomass from the Grand Banks shelf to the

742 northern part of the NADR province compared to the Gulf Stream stations (Figures

7436,7 , and 8). This trend coincided with the northeastward shoaling of the nitracline

744 along the transect. The patchiness of nanophytoplankton biomass corresponded to

745 localised increases in nutrient and light availability (e.g., station 7, 13 and 15),

746 suggesting that this size-group may respond more strongly to the alleviation of

747 nutrient limitation (e.g., nitrate), or be under looser top-down control than smaller-

748 sized phytoplankton. At the northeastern-most summer bloom station, calcified

749 coccolithphore cells did not contribute significantly to the nanophytoplankton

750 biomass $(<\sim 14 \mu \mathrm{m})$ although late summer coccolithophore blooms have been

751 documented quite regularly north of the subpolar front $\left(52-54^{\circ} \mathrm{N}\right)$ (Holligan et al.,

752 1993; Longhurst, 2007), which is at the northern boundary of our transect. North of

753 that area and in the absence of a coccolithophore bloom, the majority of summer

754 phytoplankton community biomass (mean euphotic zone [Chla] $=0.41 \mathrm{mg} \mathrm{m}^{-3}$ ) has

755 been observed to comprise of small flagellates (picoeukaryotes (18\%),

756 nanoeukaryotes (68\%) and Cocco (6\%)), with only minor contributions from

757 Synechococcus (7\%) and diatoms (1\%) (Poulton et al., 2010). This is comparable to

758 the phytoplankton community composition we observed at the northeastern end of 759 our transect. 


\subsection{Imprint of phytoplankton nitrogen utilisation on the nitrogen isotopes}

The increase in the $\delta^{15} \mathrm{~N}$ of surface suspended PN along the path of the Gulf

762 Stream and the North Atlantic Current, from 0\%o in the southwest to $\sim 5 \%$ in the

763 northeastern part of the transect, is a first order reflection of the isotopic

764 composition of the subsurface nitrate source, the degree to which this nitrate is

765 consumed by phytoplankton, and the extent of phytoplankton reliance on other $\mathrm{N}$

766 forms relative to subsurface nitrate. However, variations in the degree of

767 consumption of the supplied nitrate are unlikely to be an important driver of the

$768 \delta^{15} \mathrm{~N}$ of surface suspended PN at most stations because the isotope effect of nitrate

769 assimilation is not expressed when nitrate is completely consumed (i.e., surface

770 nitrate concentration was $<100 \mathrm{nmol} \mathrm{l}^{-1}$ at all stations except 12, 13 and 15) (Figure 771 2C).

772 Regarding the subsurface nitrate source, the basin-scale signal of $\mathrm{N}_{2}$ fixation

773 is evident as a "bolus" of low- $\delta^{15} \mathrm{~N}$ nitrate $(\sim 2.5 \pm 0.1 \%)$ in the thermocline $(\sim 200$ -

$774400 \mathrm{~m}$ ) of the southwestern stations (Figure 4B; Knapp et al. (2008)). However, $\mathrm{N}_{2}$

775 fixation need not be occurring in situ to produce this signal. Rather, its isotopic 776 imprint is advected and integrated into subtropical thermocline waters on the

777 timescale of decades through the remineralisation of low- $\delta^{15} \mathrm{~N}$ PN deriving from $\mathrm{N}_{2}$

778 fixation elsewhere in the basin (Knapp et al., 2005). By contrast, the higher $\delta^{15} \mathrm{~N}$ of

779 subsurface nitrate at the northeastern stations ( $4.7 \pm 0.2 \%$ ) is similar to the mean

$780 \quad \delta^{15} \mathrm{~N}$ of deep ocean nitrate ( $\sim 5 \%$; Sigman et al. (2000)), and derives from the

781 combined influence of Mediterranean Water, North Atlantic Central Water, and

782 Subpolar Mode Water (Talley, 2011).

783 In contrast to the $\delta^{15} \mathrm{~N}$ of subsurface nitrate, which ranged from $2.4 \%$ to

$7845.1 \%$ along the transect, $\mathrm{N}_{2}$ fixation and atmospheric $\mathrm{N}$ deposition introduce low-

$785 \delta^{15} \mathrm{~N}-\mathrm{N}$ to surface waters (-5\%o to 0\%; Carpenter et al. (1997); Knapp et al. (2008);

786 Minagawa and Wada (1986)). However, studies conducted near our southwestern

787 stations suggest that, on an annual basis, fluxes from both sources are too low to

788 account for the low $\delta^{15} \mathrm{~N}$ of PN in this region (Altabet, 1988; Knap and Jickells, 1986;

789 Knapp et al., 2008; Knapp et al., 2005; Michaels et al., 1993). Instead, the low- $\delta^{15} \mathrm{~N}$ 
790 PN to the southwest of the transect is best interpreted as the result of upper ocean $\mathrm{N}$ 791 recycling (Altabet, 1988; Fawcett et al., 2011; Fawcett et al., 2014; Treibergs et al., 792 2014): Zooplankton sustained by upper ocean PN metabolise and excrete ${ }^{15} \mathrm{~N}$ 793 depleted ammonium, the assimilation of which renders phytoplankton (i.e., PN) low 794 in $\delta^{15} \mathrm{~N}$ (Checkley and Miller, 1989; Montoya et al., 2002). The apparently stronger 795 reliance on regenerated $\mathrm{N}$ to the southwest of the transect, as implied by the $\delta^{15} \mathrm{~N}$ of $796 \mathrm{PN}$, is consistent with the observed depletion of the surface nitrate pool in this 797 region (Figure 2C).

798 From the Grand Banks shelf to the northeastern end of the transect near the 799 subarctic Atlantic, the $\delta^{15} \mathrm{~N}$ of PN gradually increases (Figure 4A), reflecting 800 increased reliance on subsurface nitrate as well as a higher $\delta^{15} \mathrm{~N}$ for the nitrate 801 supply (Figure 4B). However, removing the potentially confounding effect of 802 subsurface nitrate $\delta^{15} \mathrm{~N}$ does not remove the clear pattern of increasing PN $\delta^{15} \mathrm{~N}$ and 803 thus increasing dependence on nitrate relative to regenerated $\mathrm{N}$ from the Gulf 804 Stream to the southwest to the subarctic Atlantic to the northeast (Figure 10). 805 Stations 8 and 9, although having a similar fraction of nanophytoplankton biomass 806 as the more northeastern stations, had SST and SSS properties that were different 807 from stations further northeast (Figure S8), indicating mixing with fresher water 808 masses. This could cause the misidentification of the nitrate source and thus an 809 overcorrection of the surface $\delta^{15} \mathrm{~N}-\mathrm{PN}$ (Figure 10, central diamond pair, Table 3).

810 The increased reliance on subsurface nitrate inferred from the zonal rise in $\delta^{15} \mathrm{~N}-\mathrm{PN}$

811 is reflected in the increased biomass contribution of nanoeukaryotes and decreased 812 biomass contribution of picocyanobacteria to the phytoplankton community, from 813 the Gulf Stream to subarctic Atlantic part of the transect (Figure 10 and Table 3). 814 One caveat to the above is that using the $\delta^{15} \mathrm{~N}$ of bulk suspended PN to assess 815 autotrophic $\mathrm{N}$ assimilation patterns is not ideal since PN also contains heterotrophic 816 and detrital biomass $\mathrm{N}$, which have different $\delta^{15} \mathrm{~N}$ signatures (Fawcett et al., 2011). 817 For example, the rise in $\delta^{15 \mathrm{~N}-\mathrm{PN}}$ below the nitracline at all stations from which we 818 have sufficiently deep data (Figure 4A and S9) likely indicates a contribution of 
819 degraded detrital $\mathrm{PN}$, which is high in $\delta^{15} \mathrm{~N}$ due to the preferential remineralization 820 of ${ }^{14} \mathrm{~N}$ by heterotrophic bacteria (Altabet and McCarthy, 1986; Möbius, 2013).

821 Nitrate was easily detectable throughout surface waters of the northern 822 extent of the NADR (stations 13 and 15, Figure 2C), such that the isotope 823 discrimination during nitrate assimilation needs to be considered when inferring 824 phytoplankton reliance on nitrate versus regenerated $\mathrm{N}$ from the $\delta^{15} \mathrm{~N}$ of suspended 825 PN. Station 12 is excluded from this analysis because we have only two euphotic 826 zone measurements of nitrate $>300 \mathrm{nmol} \mathrm{l}^{-1}$, both of which are below the MLD. 827 During nitrate assimilation, phytoplankton preferentially consume ${ }^{14} \mathrm{~N}$-bearing 828 nitrate, leaving the ambient nitrate pool enriched in ${ }^{15} \mathrm{~N}$ (Sigman et al., 1999; Wada 829 and Hattori, 1978). Algal nitrate consumption thus elevates the $\delta^{15} \mathrm{~N}$ of subsurface 830 nitrate supplied to the euphotic zone by upward vertical mixing. The phytoplankton

831 PN produced from the consumption of this nitrate is lower in $\delta^{15} \mathrm{~N}$ than the nitrate 832 itself due to the isotopic fractionation that occurs during its assimilation; this is 833 quantified by the isotope effect, $\varepsilon_{\text {assim }}\left(\varepsilon_{\text {assim, }}\right.$, in \%ovs. $N_{2}$ in air, $=\left({ }^{14} \mathrm{k} /{ }^{15} \mathrm{k}-1\right) \times$ 8341000 , where ${ }^{14} \mathrm{k}$ and ${ }^{15} \mathrm{k}$ are the rate coefficients of the reaction for ${ }^{14} \mathrm{~N}$ - and ${ }^{15} \mathrm{~N}$ 835 containing nitrate, respectively). The $\delta^{15} \mathrm{~N}$ of PN increases with increasing surface 836 ocean nitrate consumption (Altabet and Francois, 1994), ultimately approximating 837 the $\delta^{15} \mathrm{~N}$ of the source nitrate upon complete nitrate consumption. We used the 838 Rayleigh model to estimate $\varepsilon_{\text {assim }}$ from the vertical profiles of nitrate concentration 839 and $\delta^{15} \mathrm{~N}$, which can then be used to predict the $\delta^{15} \mathrm{~N}$ of PN produced from the 840 assimilation of nitrate with a source concentration and $\delta^{15} \mathrm{~N}$ equal to that measured 841 at each station (Figure S9A-D; Suppl. Text 1).

842 At both stations, the $\delta^{15} \mathrm{~N}$ of suspended PN from the mixed layer is very 843 similar to the integrated product $\delta^{15} \mathrm{~N}$ predicted by the Rayleigh model (Figure S9, 844 Suppl. Text 1), suggesting a strong reliance on nitrate by the community. The 845 elevated surface nitrate concentration at station 15 could be due to its location close 846 to the margin of the subpolar gyre, where the unused nitrate concentration tends to 847 be higher than in the rest of the basin at this time of year (WOA 2013; cf. Fig. 2b in 848 Straub et al. (2013)). As such, the nitrate supply could have been advected from this 
849 perennial high-nutrient region to the northwest. However, nitrate appears to have 850 been recently (on the order of days to a week) resupplied to the surface at station 85115 as suggested by in situ [Chla], which was two times higher than expected 852 compared to remote sensing climatology for this area (Figure S5), and the relatively 853 high primary production rate $\left(\sim 2 \mu \mathrm{mol} \mathrm{l}^{-1} \mathrm{~d}^{-1}\right)$. Moreover, the mass-weighted $\delta^{15} \mathrm{~N}$ of

$854 \mathrm{PN}$ in the upper mixed layer is higher $(4.3 \%$ ) $)$ than that predicted by the integrated 855 product of the Rayleigh model ( $\sim 3 \%$; Figure S9D, integrated product); this may 856 reflect a contribution of PN produced prior to the bloom, which had a $\delta^{15} \mathrm{~N}$ of $\sim 5 \%$ o 857 due to complete consumption of the subsurface nitrate supply. The $\delta^{15} \mathrm{~N}$ of the PN 858 sampled during the cruise may not yet have been altered significantly by the 859 consumption of lower- $\delta^{15} \mathrm{~N}$, newly-supplied nitrate.

860 High $\delta^{15} \mathrm{~N}-\mathrm{PN}$ may also reflect a significant contribution from rapidly growing 861 phytoplankton (i.e., nanoeukaryotes; Figures 7D and $10 \mathrm{~A}$ ) with a $\delta^{15} \mathrm{~N}$ that is more 862 similar to the Rayleigh model's instantaneous product than integrated product, 863 since growing phytoplankton integrate over only a short period of time and thus a 864 short degree of nitrate consumption (Fawcett et al., 2011). Nitrate was present at 865 concentrations $>2 \mu \mathrm{mol} \mathrm{l}^{-1}$ throughout the mixed layer at station 15 , with a $\delta^{15} \mathrm{~N}$ 866 ranging from $6.3 \%$ to $11 \%$. Consumption of this nitrate would produce 867 instantaneous product biomass with an average $\delta^{15} \mathrm{~N}$ of $5.9 \%$; including some 868 portion of this in the suspended PN pool could easily elevate its $\delta^{15} \mathrm{~N}$ above that of 869 the predicted integrated product.

870 One final consideration is the potential effect of euphotic zone nitrification on 871 the $\delta^{15} \mathrm{~N}$ of nitrate and PN. As described above, the co-occurrence of ammonium 872 assimilation and nitrification will result in the production of low- $\delta^{15} \mathrm{~N}$ regenerated 873 nitrate, rendering it indistinguishable from other recycled $\mathrm{N}$ forms, and distinct 874 from subsurface nitrate (DiFiore et al., 2009; Fawcett et al., 2011). Thus, even if 875 euphotic zone nitrification were occurring, $\delta^{15} \mathrm{~N}-\mathrm{PN}$ would still accurately record the 876 extent of new relative to regenerated production over most of the transect.

877 However, at the stations with relatively high upper ocean nitrate 878 concentrations $(12,13$, and 15), euphotic zone PN produced from regenerated 
879 nitrate assimilation could be mistaken for PN produced by the assimilation of 880 subsurface nitrate with an isotope effect. Since regenerated nitrate will be 881 assimilated with the same $\varepsilon_{\text {assim }}$ as subsurface nitrate, the fact that mixed layer $\delta^{15} \mathrm{~N}$ $882 \mathrm{PN}$ is well predicted by the Rayleigh model does not rule out the possibility that 883 some fraction of the nitrate being assimilated was produced in the euphotic zone. 884 This can be addressed using the oxygen ( 0$)$ isotopes of nitrate $\left(\delta^{18} 0\right.$, in $\%$ vs. 885 VSMOW) in conjunction with the $\mathrm{N}$ isotopes. Briefly, co-occurring nitrate 886 assimilation and nitrification causes samples to fall above a 1:1 line in nitrate $\delta^{15} \mathrm{~N}$ 887 vs. $\delta^{18} 0$ space, whereas nitrate assimilation alone results in samples falling on the 888 1:1 line (Sigman et al., 2005; Wankel et al., 2007; Suppl. Text 2.2). Evaluation of the 889 coupled $\mathrm{N}$ and $\mathrm{O}$ isotopes of nitrate at the northeastern-most stations reveals a 1:1 890 relationship in the upper $100 \mathrm{~m}$ (Figure S9E-F), strongly indicating that euphotic 891 zone nitrification is insignificant relative to the upward transport of subsurface 892 nitrate. In sum, the PN and nitrate isotope data suggest near-complete reliance of 893 the phytoplankton community on subsurface nitrate in the mixed layer of the 894 northeastern-most stations, consistent with a zonal pattern of increasing new 895 production from the Gulf Stream to the southwest to subarctic Atlantic to the 896 northeast of the transect.

897 The dominance of cyanobacterial picoplankton biomass in the Gulf Stream 898 together with the isotopic evidence for high reliance on recycled N (Figure 10B) 899 suggests that their ecological strategy is in exploiting these $\mathrm{N}$ forms in oligotrophic 900 environments (Fawcett et al., 2011; Zubkov et al., 2003). Culture studies have 901 shown that all ecotypes of Prochlorococcus grow well on ammonium (e.g., Moore et 902 al., 2007; Moore et al., 2002), most can utilise urea, and some low-light strains will 903 grow on nitrite (Moore et al., 2002). Only recently has there been a report of nitrate 904 assimilation by cultured ecotypes (Berube et al., 2015) but their importance in the 905 ocean remains unknown. This is thought to be due to a lack of the genetic machinery 906 for nitrate reduction (Dufresne et al., 2003; Moore et al., 2002), which is an 907 energetically expensive process. There have been very few direct studies of the 908 nutritional ecology of Prochlorococcus in the field (Casey et al., 2007; Li, 1994; 
909 Martiny et al., 2009; Zubkov et al., 2003). Zubkov et al. (2003; 2005) reported high

910 in situ rates of organic $\mathrm{N}$ assimilation by marine cyanobacteria in the Arabian Sea

911 and South Atlantic subtropical front, and attributed 33\% of the total bacterial

912 turnover of amino acids to Prochlorococcus, suggesting that this allows them to

913 dominate over other autotrophs and heterotrophic bacteria in oligotrophic waters.

914 While there is some evidence that certain strains of Prochlorococcus may be able to

915 use nitrate in the environment (Casey et al., 2007; Martiny et al., 2009; Treibergs et

916 al., 2014), their overwhelming preference appears to be for reduced $\mathrm{N}$ forms. This,

917 coupled with their extremely high affinity for phosphate in the open ocean (Lomas

918 et al., 2014), underscores the adaptation of this organism to chronically oligotrophic

919 environments (Moore et al., 2002; Scanlan and Post, 2008) and explains their

920 dominance to the southwest of the transect.

921 The congruence between the N isotopes and the distribution of Synechococcus 922 along the transect is less straightforward and probably originates from the ecotype 923 diversity of this genus (Zwirglmaier et al., 2008). Indeed, Synechococcus is the most 924 ubiquitous photoautotroph in the ocean, and has been found in virtually every 925 marine environment (Campbell et al., 1997; Olson et al., 1990; Partensky et al., 926 1996). Although often discussed in the context of the subtropical ocean gyres, 927 Synechococcus tends to be more numerically abundant in nutrient-rich rather than 928 oligotrophic environments (Partensky et al., 1999a; Scanlan, 2003), which is 929 consistent with our observations (Figure S6B). Cultured marine Synechococcus 930 species have been reported to utilise ammonium, nitrite, nitrate, urea, and amino 931 acids (Collier et al., 1999; Glibert et al., 1986; Lindell et al., 1998; Moore et al., 2002; 932 Paerl, 1991), and under severe $\mathrm{N}$ deprivation, some strains will even degrade their 933 phycoerythrin protein-pigment complex as an internal N source (Kana et al., 1992; 934 Wyman et al., 1985). With the exception of three recent isolates from the Red Sea 935 that cannot assimilate nitrate (Fuller et al., 2003), all studied strains of 936 Synechococcus can utilise both nitrate and nitrite as their sole N source (Bird and 937 Wyman, 2003; Moore et al., 2002). In the environment, Synechococcus growth rates 938 correlate with ambient nitrate concentrations (Blanchot et al., 1992; Partensky et 939 al., 1999a), and natural populations of Synechococcus appear to respond to periodic 
940 nitrate inputs (DuRand et al., 2001; Glover et al., 1988). The ability to assimilate 941 both oxidised and reduced $\mathrm{N}$ forms may reflect a higher cellular $\mathrm{N}$ requirement, 942 especially given the large, $\mathrm{N}$-rich light-harvesting protein complexes

943 (phycobilisomes) that must be maintained (Scanlan, 2003). This could explain the 944 predominance of Synechococcus shallower in the water column (Figures 7B and 8B) 945 as the low light levels at the base of the euphotic zone may not yield sufficient 946 energy to reduce oxidised $\mathrm{N}$ forms. In any case, our data are consistent with the 947 competitive advantage of Synechococcus being its cosmopolitan nutritional ecology.

948 Isotopic evidence for nitrate assimilation near the nitracline appears to be 949 associated with a higher relative abundance of picoeukaryote phytoplankton 950 biomass at this depth, suggesting that picoeukaryotes, despite their small mean cell 951 size $(<2.5 \mu \mathrm{m})$, are important drivers of new production across the transect (Figure 952 8C). This is consistent with studies by Fawcett et al. $(2011 ; 2014)$ and Painter et al. 953 (2014) that demonstrated the importance of this phytoplankton group to new and 954 export production in the oligotrophic North Atlantic, due to their apparent affinity 955 for nitrate even when ambient concentrations are extremely low, as well as their 956 position deeper in the water column near the nitracline. In contrast to the 957 picoeukaryotes and consistent with the observations of Painter et al. (2014), in this 958 study the nanoeukaryotic phytoplankton contribution to biomass was most 959 important when nitrate was available near the surface or had been fairly recently 960 supplied (Figure 10A). This appears to have been the case at the two northeastern961 most stations where the $\delta^{15} \mathrm{~N}$ of nitrate was high throughout euphotic zone waters 962 (indicating partial nitrate consumption), and may point to a growth response by 963 nanoeukaryote phytoplankton groups and an increased reliance on nitrate when it 964 is abundant. Measurements of the $\delta^{15} \mathrm{~N}$ of flow-sorted phytoplankton groups would 965 help to clarify their various nutritional niches and further our understanding of the 966 role of community composition and structure in the marine nitrogen cycle across 967 biogeochemical regimes. 


\section{Conclusions}

Phytoplankton play a pivotal role in the cycling of energy and elements

971 through the ocean's food webs, and so determine both the strength and efficiency of

972 the biological pump. The broad metabolic (e.g., (in)ability for nitrate uptake) and 973 morphological (e.g., cell size) diversity in phytoplankton species often translates

974 into different biogeochemical functions (e.g., with regard to export production). This

975 study captured an ocean basin-scale gradient in surface $\mathrm{N}$ utilisation in oligotrophic

976 to mesotrophic regimes, from the subtropical North Atlantic along the Gulf Stream

977 and the North Atlantic Current up to the southern boundary of the subarctic

978 Atlantic. Increasing ecosystem reliance on subsurface nitrate (i.e., classical new 979 production), inferred from $\mathrm{N}$ species concentration measurements and the $\mathrm{N}$ 980 isotopic composition of PN and nitrate from this summer transect, was associated 981 with the shoaling of the nitracline from the Gulf Stream to the subarctic Atlantic. 982 This broad zonal pattern in autotrophic nitrate assimilation was reflected in 983 changes in the composition of the phytoplankton assemblage, as indicated by the 984 distinct distribution of phytoplankton group-specific contributions to Chla and 985 carbon biomass, found between biogeochemical provinces. This is consistent with 986 the differential $\mathrm{N}$ assimilation capabilities of the dominant phytoplankton groups in 987 each region, as well as with variations in the rate of nitrate supply to the photic zone 988 from the subtropics to the temperate oceanic provinces. Identification of the 989 phytoplankton groups that assimilate nitrate using a combination of flow cytometric 990 sorting and $\mathrm{N}$ isotope analysis would shed further light on the relationship between 991 phytoplankton diversity and N cycling in the ocean, opening up the suspended PN 992 "black box" to further mechanistic and ecological understanding.

\section{6. Acknowledgements}

994

995 - The captain and crew of the R/V Endeavor for their professionalism 
996 - Jeff Hoffman (JCVI) and Keiran Swart for assistance with CTD deployment $997 \quad$ and sampling

998 - Sean McIntee for help with flow cytometric analyses

999 - Heidi Sosik and her lab for providing the materials and data for the 1000 intercalibration of flow cytometric forward scatter and biovolume 1001 relationships

1002 - Gabriel Reygondeau for attributing the sampling stations to dynamic 1003 biogeochemical provinces

1004 - National Science Foundation grant nºCE-1136345 for funding B. B. Ward 1005 and D. M. Sigman.

1006 - The two anonymous reviewers for their helpful comments and suggestions, 1007 which helped to improve this manuscript.

1008

1009 


\section{References}

Alkire, M., Lee, C., D'Asaro, E., Perry, M., Briggs, N., Cetinićl? I., Gray, A., 2014. Net community production and export from Seaglider measurements in the North Atlantic after the spring bloom. Journal of Geophysical Research: Oceans 119 (9), 6121-6139.

Altabet, M., 1988. Variations in nitrogen isotopic composition between sinking and suspended particles: Implications for nitrogen cycling and particle transformation in the open ocean. Deep Sea Research Part A. Oceanographic Research Papers 35 (4), 535-554. Altabet, M.A., Francois, R., 1994. Sedimentary nitrogen isotopic ratio as a recorder for surface ocean nitrate utilization. Global Biogeochemical Cycles 8, 103-116. PON from the surface waters of warm-core rings. Journal of Marine Research 44 (1), 185-201.

Altieri, K.E., Fawcett, S.E., Peters, A.J., Sigman, D.M., Hastings, M.G., 2016. Marine biogenic source of atmospheric organic nitrogen in the subtropical North Atlantic. Proceedings of the National Academy of Sciences 113 (4), 925-930.

Azam, F., Fenchel, T., Field, J.G., Gray, J.S., Meyerreil, L.A., Thingstad, F., 1983. The ecological role of water-column microbes in the sea. Marine Ecology-Progress Series 10 (3), 257-263.

Barton, A.D., Finkel, Z.V., Ward, B.A., Johns, D.G., Follows, M.J., 2013. On the roles of cell size and trophic strategy in North Atlantic diatom and dinoflagellate communities. Limnology and Oceanography 58 (1), 254-266.

Barton, A.D., Lozier, M.S., Williams, R.G., 2015. Physical controls of variability in North Atlantic phytoplankton communities. Limnology and Oceanography 60 (1), 181-197.

Bertilsson, S., Berglund, O., Karl, D.M., Chisholm, S.W., 2003. Elemental composition of marine Prochlorococcus and Synechococcus: Implications for the ecological stoichiometry of the sea. Limnology and Oceanography 48 (5), 1721-1731.

Berube, P.M., Biller, S.J., Kent, A.G., Berta-Thompson, J.W., Roggensack, S.E., RoacheJohnson, K.H., Ackerman, M., Moore, L.R., Meisel, J.D., Sher, D., 2015. Physiology and evolution of nitrate acquisition in Prochlorococcus. The ISME journal 9 (5), 11951207.

Bird, C., Wyman, M., 2003. Nitrate/nitrite assimilation system of the marine picoplanktonic cyanobacterium Synechococcus sp. strain WH 8103: effect of nitrogen source and availability on gene expression. Applied and Environmental Microbiology 69 (12), 7009-7018.

Bissinger, J.E., Montagnes, D.J.S., Sharples, J., Atkinson, D., 2008. Predicting marine phytoplankton maximum growth rates from temperature: Improving on the Eppley curve using quantile regression. Limnology and Oceanography 53 (2), 487-493.

Blanchot, J., Rodier, M., Le Bouteiller, A., 1992. Effect of El Niño Southern Oscillation events on the distribution and abundance of phytoplankton in the Western Pacific Tropical Ocean along 165 E. Journal of Plankton Research 14 (1), 137-156. 
1054 Boss, E., Behrenfeld, M., 2010. In situ evaluation of the initiation of the North 1055 Atlantic phytoplankton bloom. Geophysical Research Letters 37, 5.

1056 Bower, A.S., von Appen, W.-J., 2008. Interannual Variability in the Pathways of the 1057 North Atlantic Current over the Mid-Atlantic Ridge and the Impact of Topography. 1058 Journal of Physical Oceanography 38 (1), 104-120.

1059 Braman, R.S., Hendrix, S.A., 1989. Nanogram nitrite and nitrate determination in 1060 environmental and biological materials by vanadium(iii) reduction with chemi1061 luminescence detection. Analytical Chemistry 61 (24), 2715-2718.

1062 Buck, K.R., Chavez, F.P., Campbell, L., 1996. Basin-wide distributions of living carbon 1063 components and the inverted trophic pyramid of the central gyre of the North 1064 Atlantic Ocean, summer 1993. Aquatic Microbial Ecology 10 (3), 283-298.

1065 Cabello, A.M., Latasa, M., Forn, I., G. Morán, X.A., Massana, R., 2016. Vertical 1066 distribution of major photosynthetic picoeukaryotic groups in stratified marine waters. Environmental Microbiology, n/a-n/a.

1068 Campbell, L., Liu, H., Nolla, H.A., Vaulot, D., 1997. Annual variability of phytoplankton 1069 and bacteria in the subtropical North Pacific Ocean at Station ALOHA during the 1991-1994 ENSO event. Deep Sea Research Part I: Oceanographic Research Papers 44 (2), 167-192.

1074

1075

1076

1077

1078

1079

1080

1081

1082

1083

1084

1085

1086

1087

1088

1089

1090

1091

1092

1093

1094

1095

1096

1097

Carpenter, E.J., Harvey, H.R., Fry, B., Capone, D.G., 1997. Biogeochemical tracers of the marine cyanobacterium Trichodesmium. Deep Sea Research Part I: Oceanographic Research Papers 44 (1), 27-38.

Casciotti, K., Sigman, D., Hastings, M.G., Böhlke, J., Hilkert, A., 2002. Measurement of the oxygen isotopic composition of nitrate in seawater and freshwater using the denitrifier method. Analytical Chemistry 74 (19), 4905-4912.

Casciotti, K.L., 2009. Inverse kinetic isotope fractionation during bacterial nitrite oxidation. Geochimica Et Cosmochimica Acta 73 (7), 2061-2076.

Casciotti, K.L., Sigman, D.M., Ward, B.B., 2003. Linking diversity and stable isotope fractionation in ammonia-oxidizing bacteria. Geomicrobiology Journal 20 (4), 335353.

Casey, J.R., Aucan, J.P., Goldberg, S.R., Lomas, M.W., 2013. Changes in partitioning of carbon amongst photosynthetic pico- and nano-plankton groups in the Sargasso Sea in response to changes in the North Atlantic Oscillation. Deep-Sea Research Part IiTopical Studies in Oceanography 93, 58-70.

Casey, J.R., Lomas, M.W., Mandecki, J., Walker, D.E., 2007. Prochlorococcus contributes to new production in the Sargasso Sea deep chlorophyll maximum. Geophysical Research Letters 34 (10).

Cavender-Bares, K.K., Karl, D.M., Chisholm, S.W., 2001. Nutrient gradients in the western North Atlantic Ocean: Relationship to microbial community structure and comparison to patterns in the Pacific Ocean. Deep Sea Research Part I: Oceanographic Research Papers 48 (11), 2373-2395.

Cetinić, I., Perry, M.J., D'Asaro, E., Briggs, N., Poulton, N., Sieracki, M.E., Lee, C.M., 2015. A simple optical index shows spatial and temporal heterogeneity in phytoplankton community composition during the 2008 North Atlantic Bloom Experiment. Biogeosciences 12 (7), 2179-2194. 
1098 Checkley, D.M., Miller, C.A., 1989. Nitrogen isotope fractionation by oceanic 1099 zooplankton. Deep Sea Research Part A. Oceanographic Research Papers 36 (10), 1100 1449-1456.

1101 Chisholm, S.W., 1992. Phytoplankton Size. In: Falkowski, P.G., Woodhead, A.D., 1102 Vivirito, K. (Eds.), Primary Productivity and Biogeochemical Cycles in the Sea. 1103 Springer US, pp. 213-237.

1104 Collier, J.L., Brahamsha, B., Palenik, B., 1999. The marine cyanobacterium 1105 Synechococcus sp. WH7805 requires urease (urea amiohydrolase, EC 3.5. 1.5) to 1106 utilize urea as a nitrogen source: molecular-genetic and biochemical analysis of the 1107 enzyme. Microbiology 145 (2), 447-459.

1108 d'Ovidio, F., De Monte, S., Alvain, S., Dandonneau, Y., Lévy, M., 2010. Fluid dynamical 1109 niches of phytoplankton types. Proceedings of the National Academy of Sciences of the United States of America 107 (43), 18366-18370.

Dandonneau, Y., Deschamps, P.-Y., Nicolas, J.-M., Loisel, H., Blanchot, J., Montel, Y., Thieuleux, F., Bécu, G., 2004. Seasonal and interannual variability of ocean color and composition of phytoplankton communities in the North Atlantic, equatorial Pacific and South Pacific. Deep Sea Research Part II: Topical Studies in Oceanography 51 (1-3), 303-318.

de Boyer Montégut, C., Madec, G., Fischer, A.S., Lazar, A., Iudicone, D., 2004. Mixed layer depth over the global ocean: An examination of profile data and a profilebased climatology. Journal of Geophysical Research: Oceans 109 (C12), C12003.

Deutsch, C., Sarmiento, J.L., Sigman, D.M., Gruber, N., Dunne, J.P., 2007. Spatial coupling of nitrogen inputs and losses in the ocean. Nature 445 (7124), 163-167.

DiFiore, P.J., Sigman, D.M., Dunbar, R.B., 2009. Upper ocean nitrogen fluxes in the Polar Antarctic Zone: Constraints from the nitrogen and oxygen isotopes of nitrate. Geochemistry, Geophysics, Geosystems 10 (11).

Duce, R., LaRoche, J., Altieri, K., Arrigo, K., Baker, A., Capone, D., Cornell, S., Dentener, F., Galloway, J., Ganeshram, R., 2008. Impacts of atmospheric anthropogenic nitrogen on the open ocean. Science 320 (5878), 893-897.

Dufresne, A., Salanoubat, M., Partensky, F., Artiguenave, F., Axmann, I.M., Barbe, V., Duprat, S., Galperin, M.Y., Koonin, E.V., Le Gall, F., 2003. Genome sequence of the cyanobacterium Prochlorococcus marinus SS120, a nearly minimal oxyphototrophic genome. Proceedings of the National Academy of Sciences 100 (17), 10020-10025.

Dugdale, R.C., Goering, J.J., 1967. Uptake of new and regenerated forms of nitrogen in primary productivity. Limnology and Oceanography 12 (2), 196-206.

DuRand, M.D., Olson, R.J., Chisholm, S.W., 2001. Phytoplankton population dynamics at the Bermuda Atlantic Time-series station in the Sargasso Sea. Deep-Sea Research Part Ii-Topical Studies in Oceanography 48 (8-9), 1983-2003.

Eppley, R.W., 1972. Temperature and phytoplankton growth in sea. Fishery Bulletin 70 (4), 1063-1085.

Eppley, R.W., Peterson, B.J., 1979. Particulate organic-matter flux and planktonic new production in the deep ocean. Nature 282 (5740), 677-680.

Fawcett, S.E., Lomas, M., Casey, J.R., Ward, B.B., Sigman, D.M., 2011. Assimilation of upwelled nitrate by small eukaryotes in the Sargasso Sea. Nature Geoscience 4 (10), 717-722. 
1143 Fawcett, S.E., Lomas, M.W., Ward, B.B., Sigman, D.M., 2014. The counterintuitive 1144 effect of summer - to - fall mixed layer deepening on eukaryotic new production in the Sargasso Sea. Global Biogeochemical Cycles 28 (2), 86-102. Fawcett, S.E., Ward, B.B., Lomas, M.W., Sigman, D.M., 2015. Vertical decoupling of nitrate assimilation and nitrification in the Sargasso Sea. Deep Sea Research Part I: Oceanographic Research Papers 103, 64-72. Fuller, N.J., Marie, D., Partensky, F., Vaulot, D., Post, A.F., Scanlan, D.J., 2003. Cladespecific $16 \mathrm{~S}$ ribosomal DNA oligonucleotides reveal the predominance of a single marine Synechococcus clade throughout a stratified water column in the Red Sea. Applied and Environmental Microbiology 69 (5), 2430-2443. García-Ibáñez, M.I., Pardo, P.C., Carracedo, L.I., Mercier, H., Lherminier, P., Ríos, A.F., Pérez, F.F., 2015. Structure, transports and transformations of the water masses in the Atlantic Subpolar Gyre. Progress in Oceanography 135, 18-36.

1158 Garçon, V.C., Oschlies, A., Doney, S.C., McGillicuddy, D., Waniek, J., 2001. The role of mesoscale variability on plankton dynamics in the North Atlantic. Deep Sea Research Part II: Topical Studies in Oceanography 48 (10), 2199-2226.

1160

1161 Gasol, J.M., Del Giorgio, P.A., 2000. Using flow cytometry for counting natural planktonic bacteria and understanding the structure of planktonic bacterial communities. Scientia Marina 64 (2), 197-224.

1162

1163

1164

1165 growth and photosynthetic responses to nitrogen availability in marine Synechococcus spp. Journal of Experimental Marine Biology and Ecology 101 (1-2), 199-208.

1172 picoplankton to nanomolar nitrate perturbations. Journal of Plankton Research 29 (3), 263-274.

Glover, H.E., Prézelin, B.B., Campbell, L., Campbell, M., Garside, C., 1988. A nitratedependent Synechococcus bloom in surface Sargasso Sea water. Nature 331 (6152), 161-163.

1174

1175

1176

1177

1178

1179

1180

1181

1182

1183

1184

1185

1186

Granger, J., Sigman, D.M., 2009. Removal of nitrite with sulfamic acid for nitrate N and $\mathrm{O}$ isotope analysis with the denitrifier method. Rapid Communications in Mass Spectrometry 23 (23), 3753-3762.

Grob, C., Hartmann, M., Zubkov, M.V., Scanlan, D.J., 2011. Invariable biomass-specific primary production of taxonomically discrete picoeukaryote groups across the Atlantic Ocean. Environmental Microbiology 13 (12), 3266-3274.

Gruber, N., Sarmiento, J.L., 1997. Global patterns of marine nitrogen fixation and denitrification. Global Biogeochemical Cycles 11 (2), 235-266.

Heywood, J.L., Zubkov, M.V., Tarran, G.A., Fuchs, B.M., Holligan, P.M., 2006. Prokaryoplankton standing stocks in oligotrophic gyre and equatorial provinces of the Atlantic Ocean: Evaluation of inter-annual variability. Deep Sea Research Part II: Topical Studies in Oceanography 53 (14-16), 1530-1547.

Hoch, M.P., Fogel, M.L., Kirchman, D.L., 1992. Isotope fractionation associated with ammonium uptake by a marine bacterium. Limnology and Oceanography 37 (7), 1447-1459. 
1187 Holligan, P.M., Fernandez, E., Aiken, J., Balch, W.M., Boyd, P., Burkill, P.H., Finch, M., 1188 Groom, S.B., Malin, G., Muller, K., Purdie, D.A., Robinson, C., Trees, C.C., Turner, S.M., 1189 Vanderwal, P., 1993. A biogeochemical study of the coccolithophore, Emiliania huxleyi, in the North-Atlantic. Global Biogeochemical Cycles 7 (4), 879-900. Holm-Hansen, O., Riemann, B., 1978. Chlorophyll $a$ Determination - Improvements in Methodology. Oikos 30, 438-447.

Hooks, C.E., Bidigare, R.R., Keller, M.D., Guillard, R.R., 1988. Coccoid eukaryotic marine ultraplankters with four different hplc pigment signatures. Journal of Phycology 24 (4), 571-580.

Hydes, D.J., Aoyama, M., Aminot, A., Bakker, K., Becker, S., Coverly, S., Daniel, A., Dickson, A.G., Grosso, O., Kerouel, R., van Ooijen, J., Sato, K., Tanhua, T., Woodward, E.M.S., Zhang, J.Z., 2010. Determination of dissolved nutrients (N, P, Si) in seawater with high precision and inter-comparability using gas-segmented continuous flow analysers. The GO-SHIP Repeat Hyrography Manual: a collection of expert reports and guidelines.

Irwin, A.J., Nelles, A.M., Finkel, Z.V., 2012. Phytoplankton niches estimated from field data. Limnology and Oceanography 57 (3), 787-797.

Joint, I., Pomroy, A., Savidge, G., Boyd, P., 1993. Size-fractionated primary productivity in the northeast Atlantic in May-July 1989. Deep Sea Research Part II: Topical Studies in Oceanography 40 (1), 423-440.

Jones, R., 1991. An improved fluorescence method for the determination of nanomolar concentrations of ammonium in natural waters. Limnology and Oceanography 36 (4), 814-819.

Kana, T.M., Feiwel, N.L., Flynn, L.C., 1992. Nitrogen starvation in marine Synechococcus strains: clonal differences in phycobiliprotein breakdown and energy coupling. Marine Ecology-Progress Series 88, 75-75.

Kirkham, A.R., Lepere, C., Jardillier, L.E., Not, F., Bouman, H., Mead, A., Scanlan, D.J., 2013. A global perspective on marine photosynthetic picoeukaryote community structure. ISME J 7 (5), 922-936.

Knap, A., Jickells, T., 1986. Significance of atmospheric-derived fixed nitrogen on productivity of the Sargasso Sea. Nature 320, 158-160.

Knapp, A.N., DiFiore, P.J., Deutsch, C., Sigman, D.M., Lipschultz, F., 2008. Nitrate isotopic composition between Bermuda and Puerto Rico: Implications for N2 fixation in the Atlantic Ocean. Global Biogeochemical Cycles 22 (3).

Knapp, A.N., Sigman, D.M., Lipschultz, F., 2005. N isotopic composition of dissolved organic nitrogen and nitrate at the Bermuda Atlantic Time - series Study site. Global Biogeochemical Cycles 19 (1).

Laney, S.R., Sosik, H.M., 2014. Phytoplankton assemblage structure in and around a massive under-ice bloom in the Chukchi Sea. Deep Sea Research Part II: Topical Studies in Oceanography 105 (0), 30-41.

Laws, E.A., Letelier, R.M., Karl, D.M., 2014. Estimating the compensation irradiance in the ocean: The importance of accounting for non-photosynthetic uptake of inorganic carbon. Deep Sea Research Part I: Oceanographic Research Papers 93 (0), $35-40$. 
1231 Legendre, L., Gosselin, M., 1997. Estimation of N or C uptake rates by phytoplankton 1232 using N-15 or C-13: Revisiting the usual computation formulae. Journal of Plankton 1233 Research 19 (2), 263-271.

1234 Letelier, R.M., Karl, D.M., Abbott, M.R., Bidigare, R.R., 2004. Light driven seasonal patterns of chlorophyll and nitrate in the lower euphotic zone of the North Pacific Subtropical Gyr. Limnology and Oceanography 49 (2), 508-519.

1238

1239 Li, W.K., 1994. Primary production of prochlorophytes, cyanobacteria, and eucaryotic ultraphytoplankton: measurements from flow cytometric sorting. Limnology and Oceanography 39 (1), 169-175.

1240

1241

1242

1243

1244

1245 Li, W.K.W., 1995. Composition of ultraphytoplankton in the central North Atlantic. Marine Ecology Progress Series 122, 1-8.

Li, W.K.W., 1997. Cytometric diversity in marine ultraphytoplankton. Limnology and Oceanography 42 (5), 874-880.

1246 Li, W.K.W., 2002. Macroecological patterns of phytoplankton in the northwestern North Atlantic Ocean. Nature 419 (6903), 154-157.

1247

1248

1249

1250

1251

1252

1253

1254

1255

1256

1257

1258

1259

1260

1261

1262

1263

1264

1265

1266

1267

1268

1269

1270

1271

1272

1273

1274

1275 Li, W.K.W., Harrison, W.G., 2001. Chlorophyll, bacteria and picophytoplankton in ecological provinces of the North Atlantic. Deep Sea Research Part II: Topical Studies in Oceanography 48 (10), 2271-2293.

Lindell, D., Padan, E., Post, A.F., 1998. Regulation of ntcA expression and nitrite uptake in the marine Synechococcus sp. strain WH 7803. Journal of Bacteriology 180 (7), 1878-1886.

Liu, K.-K., Kao, S.-J., Chiang, K.-P., Gong, G.-C., Chang, J., Cheng, J.-S., Lan, C.-Y., 2013. Concentration dependent nitrogen isotope fractionation during ammonium uptake by phytoplankton under an algal bloom condition in the Danshuei estuary, northern Taiwan. Marine Chemistry 157, 242-252.

Lochte, K., Ducklow, H.W., Fasham, M.J.R., Stienen, C., 1993. Plankton succession and carbon cycling at $47^{\circ} \mathrm{N}-20^{\circ} \mathrm{W}$ during the JGOFS North-Atlantic bloom experiment. Deep-Sea Research Part Ii-Topical Studies in Oceanography 40 (1-2), 91-114.

Lomas, M.W., Bonachela, J.A., Levin, S.A., Martiny, A.C., 2014. Impact of ocean phytoplankton diversity on phosphate uptake. Proceedings of the National Academy of Sciences 111 (49), 17540-17545.

Lomas, M.W., Lipschultz, F., 2006. Forming the primary nitrite maximum: Nitrifiers or phytoplankton? Limnology and Oceanography 51 (5), 2453-2467.

Lomas, M.W., Moran, S.B., 2011. Evidence for aggregation and export of cyanobacteria and nano-eukaryotes from the Sargasso Sea euphotic zone. Biogeosciences 8 (1), 203-216.

Longhurst, A., 2007. Ecological Geography of the Sea. Academic Press, London.

Macko, S.A., Estep, M.L.F., Engel, M.H., Hare, P., 1986. Kinetic fractionation of stable nitrogen isotopes during amino acid transamination. Geochimica Et Cosmochimica Acta 50 (10), 2143-2146.

Marañón, E., Cermeno, P., Latasa, M., Tadonléké, R.D., 2012. Temperature, resources, and phytoplankton size structure in the ocean. Limnology and Oceanography 57 (5), 1266.

Marañon, E., Holligan, P.M., Barciela, R., González, N., Mouriño, B., Pazó, M.J., Varela, M., 2001. Patterns of phytoplankton size structure and productivity in contrasting

1276 open-ocean environments. Marine Ecology Progress Series 216, 43-56. 
1277 Marconi, D., Weigand, M.A., Rafter, P.A., McIlvin, M.R., Forbes, M., Casciotti, K.L., 1278 Sigman, D.M., 2015. Nitrate isotope distributions on the US GEOTRACES North Atlantic cross-basin section: Signals of polar nitrate sources and low latitude nitrogen cycling. Marine Chemistry 177, 143-156.

Marie, D., Partensky, F., Jacquet, S., Vaulot, D., 1997. Enumeration and cell cycle analysis of natural populations of marine picoplankton by flow cytometry using the nucleic acid stain SYBR Green I. Applied and Environmental Microbiology 63 (1), 186-193.

Mariotti, A., Germon, J., Hubert, P., Kaiser, P., Letolle, R., Tardieux, A., Tardieux, P., 1981. Experimental determination of nitrogen kinetic isotope fractionation: some principles; illustration for the denitrification and nitrification processes. Plant and soil 62 (3), 413-430.

Marra, J.F., Lance, V.P., Vaillancourt, R.D., Hargreaves, B.R., 2014. Resolving the ocean's euphotic zone. Deep Sea Research Part I: Oceanographic Research Papers 83 (0), 45-50.

Martiny, A.C., Kathuria, S., Berube, P.M., 2009. Widespread metabolic potential for nitrite and nitrate assimilation among Prochlorococcus ecotypes. Proceedings of the National Academy of Sciences 106 (26), 10787-10792.

McIlvin, M.R., Casciotti, K.L., 2011. Technical updates to the bacterial method for nitrate isotopic analyses. Analytical Chemistry 83 (5), 1850-1856.

Michaels, A.F., Siegel, D.A., Johnson, R.J., Knap, A.H., Galloway, J.N., 1993. Episodic inputs of atmospheric nitrogen to the Sargasso Sea: Contributions to new production and phytoplankton blooms. Global Biogeochemical Cycles 7, 339-351.

Minagawa, M., Wada, E., 1986. Nitrogen isotope ratios of red tide organisms in the East China Sea: a characterization of biological nitrogen fixation. Marine Chemistry 19 (3), 245-259.

Möbius, J., 2013. Isotope fractionation during nitrogen remineralization (ammonification): Implications for nitrogen isotope biogeochemistry. Geochimica Et Cosmochimica Acta 105, 422-432.

Montoya, J.P., Carpenter, E.J., Capone, D.G., 2002. Nitrogen fixation and nitrogen isotope abundances in zooplankton of the oligotrophic North Atlantic. Limnology and Oceanography 47 (6), 1617-1628.

Moore, C.M., Mills, M.M., Arrigo, K.R., Berman-Frank, I., Bopp, L., Boyd, P.W., Galbraith, E.D., Geider, R.J., Guieu, C., Jaccard, S.L., Jickells, T.D., La Roche, J., Lenton, T.M., Mahowald, N.M., Maranon, E., Marinov, I., Moore, J.K., Nakatsuka, T., Oschlies, A., Saito, M.A., Thingstad, T.F., Tsuda, A., Ulloa, O., 2013. Processes and patterns of oceanic nutrient limitation. Nature Geosci 6 (9), 701-710.

Moore, C.M., Mills, M.M., Langlois, R., Milne, A., Achterberg, E.P., LaRoche, J., Geider, R.J., 2008. Relative influence of nitrogen and phosphorous availability on phytoplankton physiology and productivity in the oligotrophic sub-tropical North Atlantic Ocean. Limnology and Oceanography 53 (1), 291-305.

Moore, L.R., Coe, A., Zinser, E.R., Saito, M.A., Sullivan, M.B., Lindell, D., Frois-Moniz, K., Waterbury, J., Chisholm, S.W., 2007. Culturing the marine cyanobacterium Prochlorococcus. Limnol. Oceanogr. Methods 5, 353-362. 
1321 Moore, L.R., Post, A.F., Rocap, G., Chisholm, S.W., 2002. Utilization of different 1322 nitrogen sources by the marine cyanobacteria Prochlorococcus and Synechococcus. 1323 Limnology and Oceanography 47 (4), 989-996.

1324 Morel, A., Berthon, J.F., 1989. Surface pigments, algal biomass profiles, and potential production of the euphotic layer - relationships reinvestigated in view of remotesensing applications. Limnology and Oceanography 34 (8), 1545-1562.

Morel, A., Maritorena, S., 2001. Bio-optical properties of oceanic waters: A reappraisal. Journal of Geophysical Research: Oceans 106 (C4), 7163-7180.

Nielsdóttir, M.C., Moore, C.M., Sanders, R., Hinz, D.J., Achterberg, E.P., 2009. Iron limitation of the postbloom phytoplankton communities in the Iceland Basin. Global Biogeochemical Cycles 23 (3), n/a-n/a.

Olson, R.J., Chisholm, S.W., Zettler, E.R., Altabet, M.A., Dusenberry, J.A., 1990. Spatial and temporal distributions of prochlorophyte picoplankton in the North Atlantic Ocean. Deep Sea Research Part A. Oceanographic Research Papers 37 (6), 10331051.

Olson, R.J., Zettler, E.R., Anderson, O.K., 1989. Discrimination of eukaryotic phytoplankton cell types from light scatter and autofluorescence properties measured by flow cytometry. Cytometry 10 (5), 636-643.

Oschlies, A., 2002. Nutrient supply to the surface waters of the North Atlantic: A model study. Journal of Geophysical Research: Oceans 107 (C5), 14-11-14-13.

Paerl, H.W., 1991. Ecophysiological and trophic implications of light-stimulated amino acid utilization in marine picoplankton. Applied and Environmental Microbiology 57 (2), 473-479.

Painter, S.C., Patey, M.D., Tarran, G.A., Torres-Valdès, S., 2014. Picoeukaryote distribution in relation to nitrate uptake in the oceanic nitracline. Aquatic Microbial Ecology 72 (3), 195-213.

Partensky, F., Blanchot, J., Lantoine, F., Neveux, J., Marie, D., 1996. Vertical structure of picophytoplankton at different trophic sites of the tropical northeastern Atlantic Ocean. Deep Sea Research Part I: Oceanographic Research Papers 43 (8), 11911213.

Partensky, F., Blanchot, J., Vaulot, D., 1999a. Differential distribution and ecology of Prochlorococcus and Synechococcus in oceanic waters: a review. Bulletin Institut Oceanographique Monaco numero special, 457-476.

Partensky, F., Hess, W.R., Vaulot, D., 1999b. Prochlorococcus, a marine photosynthetic prokaryote of global significance. Microbiology and Molecular Biology Reviews 63 (1), 106-127.

Pennock, J.R., Velinsky, D.J., Ludlam, J.M., Sharp, J.H., Fogel, M.L., 1996. Isotopic fractionation of ammonium and nitrate during uptake by Skeletonema costatum: Implications for $\delta 15 \mathrm{~N}$ dynamics under bloom conditions. Limnology and Oceanography 41 (3), 451-459.

Pomeroy, L.R., 1974. Oceans food web, a changing paradigm. Bioscience 24 (9), 499504.

Poulton, A.J., Charalampopoulou, A., Young, J.R., Tarran, G.A., Lucas, M.I., Quartly, G.D., 2010. Coccolithophore dynamics in non-bloom conditions during late summer in the central Iceland Basin (July-August 2007). Limnology and Oceanography 55 (4), 1601-1613. 
1367 Qi, H., Coplen, T.B., Geilmann, H., Brand, W.A., Böhlke, J., 2003. Two new organic 1368 reference materials for $\delta 13 \mathrm{C}$ and $\delta 15 \mathrm{~N}$ measurements and a new value for the $\delta 13 \mathrm{C}$ of NBS 22 oil. Rapid Communications in Mass Spectrometry 17 (22), 2483-2487. Raimbault, P., Rodier, M., Taupier-Letage, I., 1988. Size fraction of phytoplankton in the Ligurian Sea and the Algerian Basin (Mediterranean Sea): Size distribution versus total concentration. Marine Microbial Food Webs 3 (1), 1-7. Reygondeau, G., Longhurst, A., Martinez, E., Beaugrand, G., Antoine, D., Maury, O., 2013. Dynamic biogeochemical provinces in the global ocean. Global Biogeochemical Cycles 27 (4), 1046-1058.

1376

Rodríguez, J., Blanco, J.M., Jiménez-Gómez, F., Echevarría, F., Gil, J., Rodríguez, V., Ruiz, J., Bautista, B., Guerrero, F., 1998. Patterns in the size structure of the phytoplankton community in the deep fluorescence maximum of the Alboran Sea (southwestern mediterranean). Deep Sea Research Part I: Oceanographic Research Papers 45 (10), 1577-1593. Rynearson, T.A., Richardson, K., Lampitt, R.S., Sieracki, M.E., Poulton, A.J., vertical flux in the sub-polar North Atlantic. Deep Sea Research Part I: Oceanographic Research Papers 82, 60-71. Lamborg, C.H., 2014. Multiple nutrient stresses at intersecting Pacific Ocean biomes detected by protein biomarkers. Science 345 (6201), 1173-1177. Sambrotto, R.N., Martin, J.H., Broenkow, W.W., Carlson, C., Fitzwater, S.E., 1993. Nitrate utilization in surface waters of the Iceland Basin during spring and summer of 1989. Deep Sea Research Part II: Topical Studies in Oceanography 40 (1), 441457.

Scanlan, D.J., 2003. Physiological diversity and niche adaptation in marine Synechococcus. Advances in microbial physiology 47, 1-64. and connection to the nitrogen cycle. In: Capone, D.G., Bronk, D.A., Mulholland, M.R., Carpenter, E.J. (Eds.), Nitrogen in the marine environment. Academic Press, San Diego, CA, p. 1073-1195.

Schlitzer, R., 2015. Ocean Data View, http://odv.awi.de/. http://odv.awi.de/. Sieburth, J.M., Smetacek, V., Lenz, J., 1978. Pelagic ecosystem structure: Heterotrophic compartments of the plankton and their relationship to plankton size fractions 1. Limnology and Oceanography 23 (6), 1256-1263. sequential silicate and nitrate depletion during the 1989 North Atlantic spring bloom. Deep-Sea Research Part Ii-Topical Studies in Oceanography 40 (1-2), 213225. nitrate in the Southern Ocean: consumption of nitrate in surface waters. Global Biogeochemical Cycles 13 (4), 1149-1166. 
1412 Sigman, D., Casciotti, K., Andreani, M., Barford, C., Galanter, M., Böhlke, J., 2001. A 1413 bacterial method for the nitrogen isotopic analysis of nitrate in seawater and 1414 freshwater. Analytical Chemistry 73 (17), 4145-4153.

1415 Sigman, D.M., Granger, J., DiFiore, P.J., Lehmann, M.M., Ho, R., Cane, G., van Geen, A., 1416 2005. Coupled nitrogen and oxygen isotope measurements of nitrate along the eastern North Pacific margin. Global Biogeochemical Cycles 19 (4).

Silfer, J., Engel, M., Macko, S., 1992. Kinetic fractionation of stable carbon and nitrogen isotopes during peptide bond hydrolysis: experimental evidence and geochemical implications. Chemical Geology: Isotope Geoscience Section 101 (3-4), 211-221.

Smart, S.M., Fawcett, S.E., Thomalla, S.J., Weigand, M.A., Reason, C.J., Sigman, D.M., 2015. Isotopic evidence for nitrification in the Antarctic winter mixed layer. Global Biogeochemical Cycles 29 (4), 427-445.

Straub, M., Tremblay, M., Sigman, D., Studer, A., Ren, H., Toggweiler, J., Haug, G., 2013. Nutrient conditions in the subpolar North Atlantic during the last glacial period reconstructed from foraminifera - bound nitrogen isotopes. Paleoceanography 28 (1), 79-90.

Talley, L.D., 2011. Descriptive physical oceanography: an introduction. Academic press.

Tarran, G.A., Heywood, J.L., Zubkov, M.V., 2006. Latitudinal changes in the standing stocks of nano- and picoeukaryotic phytoplankton in the Atlantic Ocean. Deep Sea Research Part II: Topical Studies in Oceanography 53 (14-16), 1516-1529.

Tarran, G.A., Zubkov, M.V., Sleigh, M.A., Burkill, P.H., Yallop, M., 2001. Microbial community structure and standing stocks in the NE Atlantic in June and July of 1996. Deep-Sea Research Part Ii-Topical Studies in Oceanography 48 (4-5), 963-985.

Treibergs, L.A., Fawcett, S.E., Lomas, M.W., Sigman, D.M., 2014. Nitrogen isotopic response of prokaryotic and eukaryotic phytoplankton to nitrate availability in Sargasso Sea surface waters. Limnol. Oceanogr 59 (3), 972-985.

Troupin, C., Barth, A., Sirjacobs, D., Ouberdous, M., Brankart, J.-M., Brasseur, P., Rixen, M., Alvera-Azcarate, A., Belounis, M., Capet, A., Lenartz, F., Toussaint, M.-E., Beckers, J.-M., 2012. Generation of analysis and consistent error fields using the Data Interpolating Variational Analysis (Diva). Ocean Modelling 52-53, 90-101.

Vaulot, D., Eikrem, W., Viprey, M., Moreau, H., 2008. The diversity of small eukaryotic phytoplankton $(\leq 3 \mu \mathrm{m})$ in marine ecosystems. FEMS microbiology reviews 32 (5), 795-820.

Verity, P.G., Robertson, C.Y., Tronzo, C.R., Andrews, M.G., Nelson, J.R., Sieracki, M.E., 1992. Relationships between cell-volume and the carbon and nitrogen-content of marine photosynthetic nanoplankton. Limnology and Oceanography 37 (7), 14341446.

Wada, E., Hattori, A., 1978. Nitrogen isotope effects in the assimilation of inorganic nitrogenous compounds. Geo Microbiology 7 (7), 85-101.

Wankel, S.D., Kendall, C., Pennington, J.T., Chavez, F.P., Paytan, A., 2007. Nitrification in the euphotic zone as evidenced by nitrate dual isotopic composition: Observations from Monterey Bay, California. Global Biogeochemical Cycles 21 (2). 
1456 Weigand, M.A., Foriel, J., Barnett, B., Oleynik, S., Sigman, D.M., 2016. Updates to 1457 instrumentation and protocols for isotopic analysis of nitrate by the denitrifier 1458 method. Rapid Communications in Mass Spectrometry 30 (12), 1365-1383.

1459 Woodward, E.M.S., Rees, A.P., 2001. Nutrient distributions in an anticyclonic eddy in 1460 the North East Atlantic Ocean, with reference to nanomolar ammonium 1461 concentrations. Deep Sea Research Part II: Topical Studies in Oceanography 48 (41462 5), 775-794.

1463 Wyman, M., Gregory, R., Carr, N., 1985. Novel role for phycoerythrin in a marine 1464 cyanobacterium, Synechococcus strain DC2. Science 230 (4727), 818-820.

1465 Yool, A., Martin, A.P., Fernández, C., Clark, D.R., 2007. The significance of nitrification 1466 for oceanic new production. Nature 447 (7147), 999-1002. Zinser, E.R., Coe, A., Johnson, Z.I., Martiny, A.C., Fuller, N.J., Scanlan, D.J., Chisholm, S.W., 2006. Prochlorococcus Ecotype Abundances in the North Atlantic Ocean As Revealed by an Improved Quantitative PCR Method. Applied and Environmental Microbiology 72 (1), 723-732. Zubkov, M.V., Fuchs, B.M., Tarran, G.A., Burkill, P.H., Amann, R., 2003. High rate of uptake of organic nitrogen compounds by Prochlorococcus cyanobacteria as a key to their dominance in oligotrophic oceanic waters. Applied and Environmental Microbiology 69 (2), 1299-1304. Zubkov, M.V., Sleigh, M.A., Tarran, G.A., Burkill, P.H., Leakey, R.J.G., 1998. Picoplanktonic community structure on an Atlantic transect from $50^{\circ} \mathrm{N}$ to $50^{\circ} \mathrm{S}$. Deep Sea Research Part I: Oceanographic Research Papers 45 (8), 1339-1355. Zubkov, M.V., Tarran, G.A., 2005. Amino acid uptake of Prochlorococcus spp. in surface waters across the South Atlantic Subtropical Front. Aquatic Microbial

1481 Zwirglmaier, K., Jardillier, L., Ostrowski, M., Mazard, S., Garczarek, L., Vaulot, D., Not, 1482 F., Massana, R., Ulloa, O., Scanlan, D.J., 2008. Global phylogeography of marine Synechococcus and Prochlorococcus reveals a distinct partitioning of lineages among 1485 oceanic biomes. Environmental Microbiology 10 (1), 147-161. 
Figure 1. Bathymetric map of stations in the southwest (black symbols), shelf (grey symbol) and northeast (white symbols) section of the transect.

Figure 2. Section plots of (A) temperature (colour shaded), (B) salinity (colour shaded), and (C) nitrate concentration (colour shaded and contour lines) along the transect. Contour lines in A and B represent the potential density anomaly (sigmatheta). Dotted profiles are associated with station numbers listed at the top of the figure. The higher spatial frequency of the surface values is the result of 6-hourly underway sampling. The thick grey dashed line indicates the depth of the nitracline.

Figure 3. Depth section plots of (A) suspended particulate organic nitrogen and (B) suspended particulate organic carbon concentration. The thick grey dashed line indicates the depth of the nitracline. Transect station numbers are designated at the top of the figure.

Figure 4. Depth section plots of $(\mathrm{A})$ the $\mathrm{N}$ isotopic composition of suspended particulate organic nitrogen $\left(\delta^{15} \mathrm{~N}-\mathrm{PN}\right)$ with contour lines indicating PN concentration $\left(\mu \mathrm{mol} \mathrm{l}{ }^{-1}\right)$, and (B) the $\mathrm{N}$ isotopic composition of nitrate $\left(\delta^{15} \mathrm{~N}^{-\mathrm{NO}_{3}}{ }^{-}\right)$ with $\mathrm{NO}_{3}{ }^{-}$concentration contour lines $\left(\mu \mathrm{mol} \mathrm{l}^{-1}\right)$. Station numbers are listed at the top of the figure. The thick grey dashed line indicates the depth of the nitracline and the grey circles indicate samples where the $\mathrm{PN}$ or $\mathrm{NO}_{3}$ - concentration was too low for its isotopic composition to be measured.

Figure 5. Depth section plots of (A) chlorophyll $a$ and (B) combined pico- and nanophytoplankton carbon biomass concentration along the transect course. Dotted profile samples are associated with station numbers listed at the top of the figure. The thick grey dashed line indicates the depth of the nitracline and the thick white dashed line represents the light compensation depth $\left(\mathrm{Z}_{\text {Ic }}\right.$ at 0.17 mol PAR quanta $\mathrm{m}^{-2}$ day $^{-1}$ ). 
Figure 6. Depth-integrated chlorophyll $a$ ( $\Sigma$ Chla) in each size fraction $(<2 \mu \mathrm{m}, 2-20$ $\mu \mathrm{m}$ and $>20 \mu \mathrm{m}$ ) above the light compensation depth ( $\mathrm{Z}_{\mathrm{Ic}}$, see Table 1) as a percentage of the total integrated Chla measured at each station (solid black line).

Figure 7. Depth section plots of the carbon biomass concentration of (A) Prochlorococcus, (B) Synechococcus, (C) picoeukaryotes, and (D) nanophytoplankton as enumerated by flow cytometry across the transect course. Dotted profile samples are associated with the station numbers listed at the top of the figure. The thick grey dashed line indicates the depth of the nitracline. Note the difference in colour bar scale for each phytoplankton group.

Figure 8. Depth section plots of the proportion of biomass represented by (A) Prochlorococcus, (B) Synechococcus, (C) picoeukaryotes, and (D) nanoeukaryotes as determined by flow cytometry. The thick grey dashed line indicates the depth of the nitracline and the thick white dashed line represents the light compensation depth ( $\mathrm{Z}_{\text {Ic }}$ at 0.17 mol PAR quanta $\mathrm{m}^{-2}$ day-1$^{-1}$ ). Dotted profile samples are associated with the station numbers listed at the top of the figure. Samples with a potentially unrepresentative population estimates ( $<250$ nanophytoplankton cells counted) are greyed-out. Note that the different phytoplankton groups are plotted using different colour scales selected to emphasise their distribution patterns.

Figure 9. Depth section plots of $(\mathrm{A})$ inorganic carbon fixation rate (transport rate; $\rho D I C)$ and (B) inorganic carbon fixation rate normalised to flow cytometry-derived phytoplankton biomass (specific rate; VDIC). The thick grey dashed line indicates the depth of the nitracline. Dotted profile samples are associated with the station numbers listed at the top of the figure.

Figure 10. The distribution of relative nanoeukaryote $(A)$ and picocyanobacteria (B) depth-integrated carbon biomass contribution as a function of the upper ocean mass-weighted $\delta^{15} \mathrm{~N}$ of PN minus the $\delta^{15} \mathrm{~N}$ of the subsurface nitrate source $\left(\delta^{15} \mathrm{~N}_{\mathrm{PN}}\right.$ - 


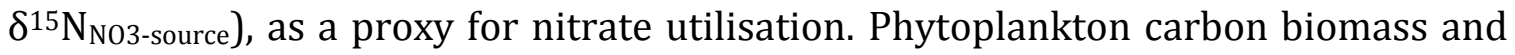
$\delta^{15} \mathrm{~N}-\mathrm{PN}$ data from each station (excluding station 7 , see Methods section) are from the surface to the nitracline depth or the MLD, whichever was deepest. Station symbols as in Figure 1. 
Figure 1. Bathymetric map of stations in the southwest (black symbols), shelf (grey symbol) and northeast (white symbols) section of the transect. The stations belong to the biogeographical provinces (sensu Longhurst 2007) of the Gulf Stream (GFST, circles), Northwest Atlantic shelves (NWCS, star), North Atlantic Drift (NADR, diamonds) and Atlantic subarctic (SARC, square).

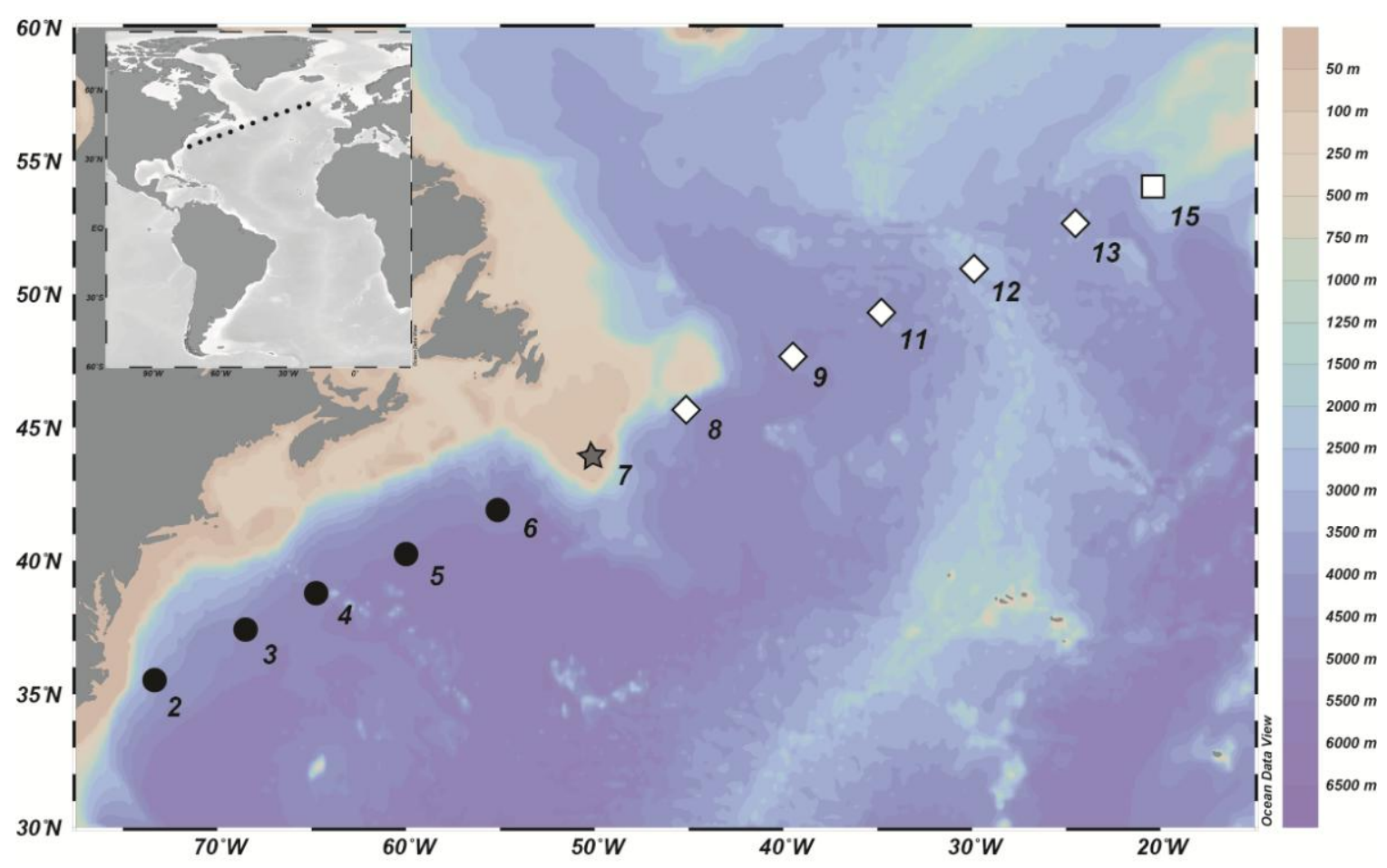


Figure 2. Section plots of (A) temperature (colour shaded), (B) salinity (colour shaded), and (C) nitrate concentration (colour shaded) along the transect. Contour lines represent the potential density anomaly (sigma-theta). Dotted profiles are associated with station numbers listed at the top of the figure. The higher spatial frequency of the surface values is the result of 6-hourly underway sampling. The thick grey dashed line indicates the depth of the nitracline $\left(\left[\mathrm{NO}_{3}^{-}\right]=300 \mathrm{nmol} \mathrm{l}^{-1}\right)$.

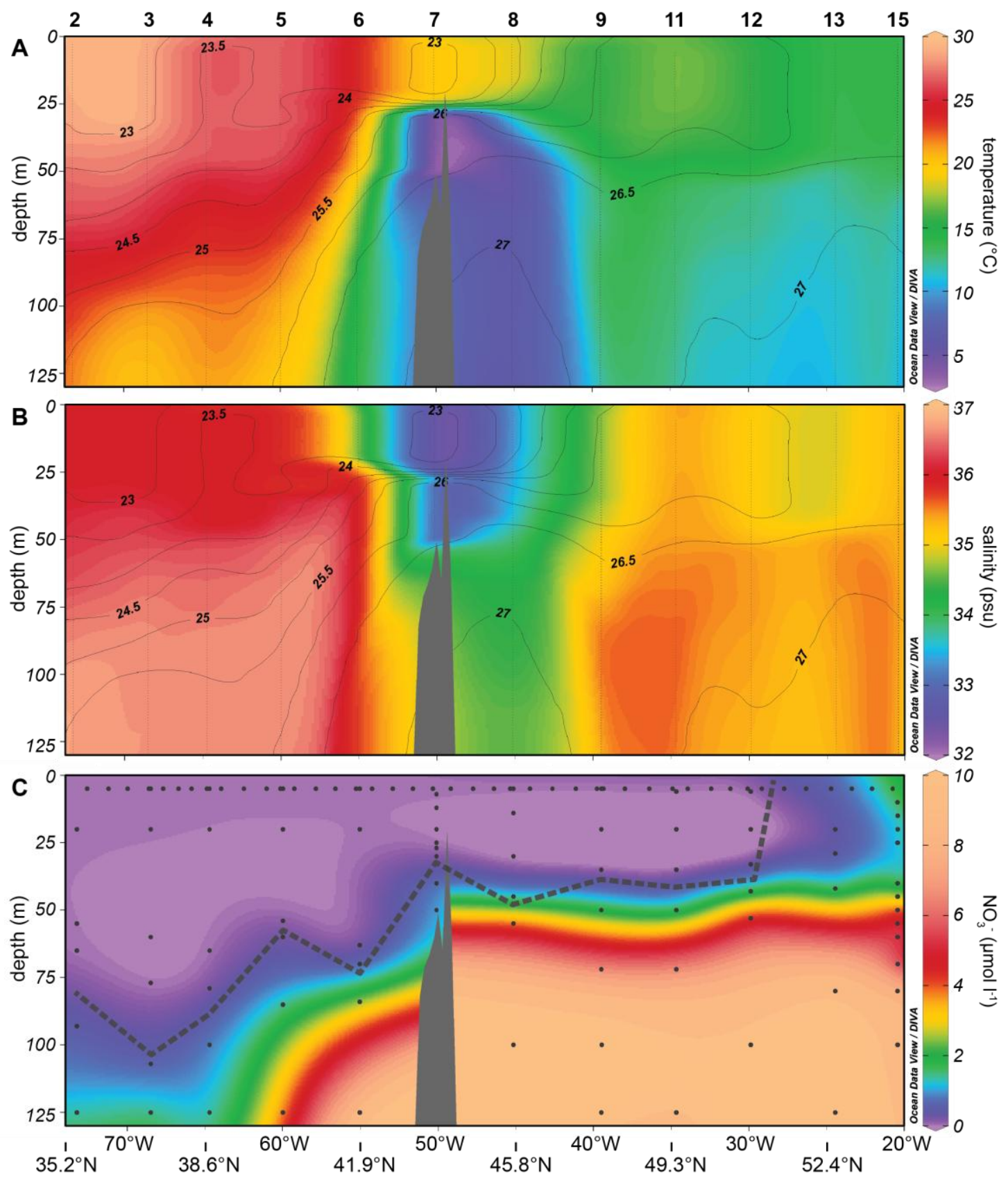


Figure 3. Depth section plots of (A) suspended particulate organic nitrogen and (B) suspended particulate organic carbon concentration. The thick black dashed line indicates the depth of the nitracline $\left(\left[\mathrm{NO}_{3}^{-}\right]=300 \mathrm{nmol} \mathrm{l}^{-1}\right)$. Transect station numbers are designated at the top of the figure.

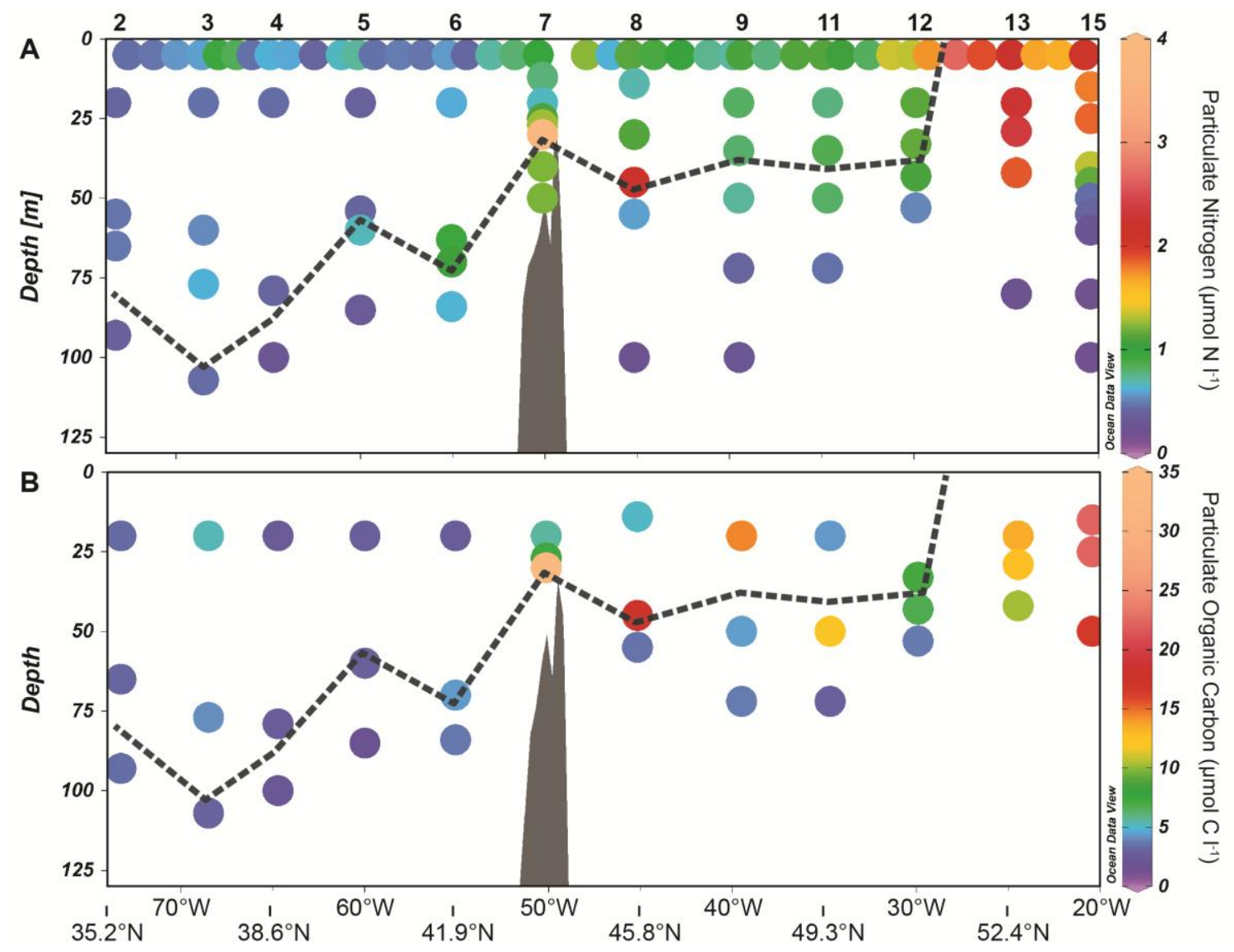


Figure 4. Depth section plots of $(A)$ the $N$ isotopic composition of suspended particulate organic nitrogen $\left(\delta^{15} \mathrm{~N} P \mathrm{~N}\right)$ with contour lines indicating PN concentration ( $\mu \mathrm{mol} \mathrm{l-1})$, and (B) the $\mathrm{N}$ isotopic composition of nitrate $\left(\delta^{15} \mathrm{~N} \mathrm{NO}_{3}^{-}\right)$ with $\mathrm{NO}_{3}{ }^{-}$concentration contour lines $\left(\mu \mathrm{mol} \mathrm{l}^{-1}\right)$. Station numbers are listed at the top of the figure. The thick dashed black line indicates the depth of the nitracline $\left(\left[\mathrm{NO}_{3}{ }^{-}\right]=300 \mathrm{nmol} \mathrm{l}^{-1}\right)$ and the grey circles indicate samples where the $\mathrm{PN}$ or $\mathrm{NO}_{3}{ }_{3}^{-}$ concentration was too low for its isotopic composition to be measured.

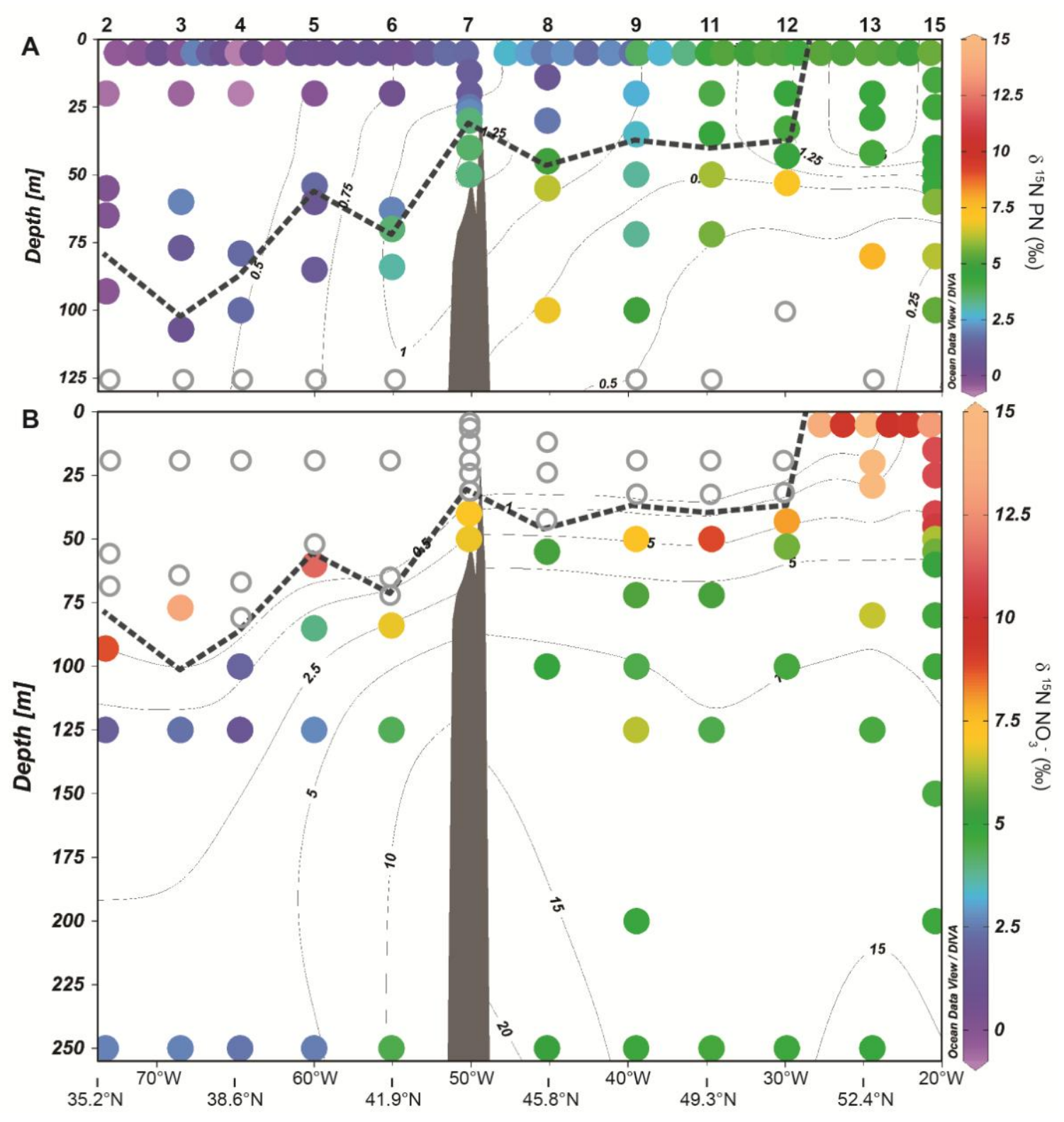


Figure 5. The distribution of relative nanoeukaryote (A) and picocyanobacteria (B) depth-integrated carbon biomass contribution as a function of the upper ocean mass-weighted $\delta^{15} \mathrm{~N}$ of PN minus the $\delta^{15} \mathrm{~N}$ of the subsurface nitrate source $\left(\delta^{15} \mathrm{~N}_{\mathrm{PN}}\right.$ $\delta^{15} \mathrm{~N}_{\mathrm{N} 03 \text {-source }}$ ), as a proxy for nitrate utilisation. Phytoplankton carbon biomass and PN $\delta^{15} \mathrm{~N}$ data from each station (excluding station 7 , see Methods section) are from the surface to the nitracline depth or the MLD, whichever was deepest. Station symbols as in Figure 1. 


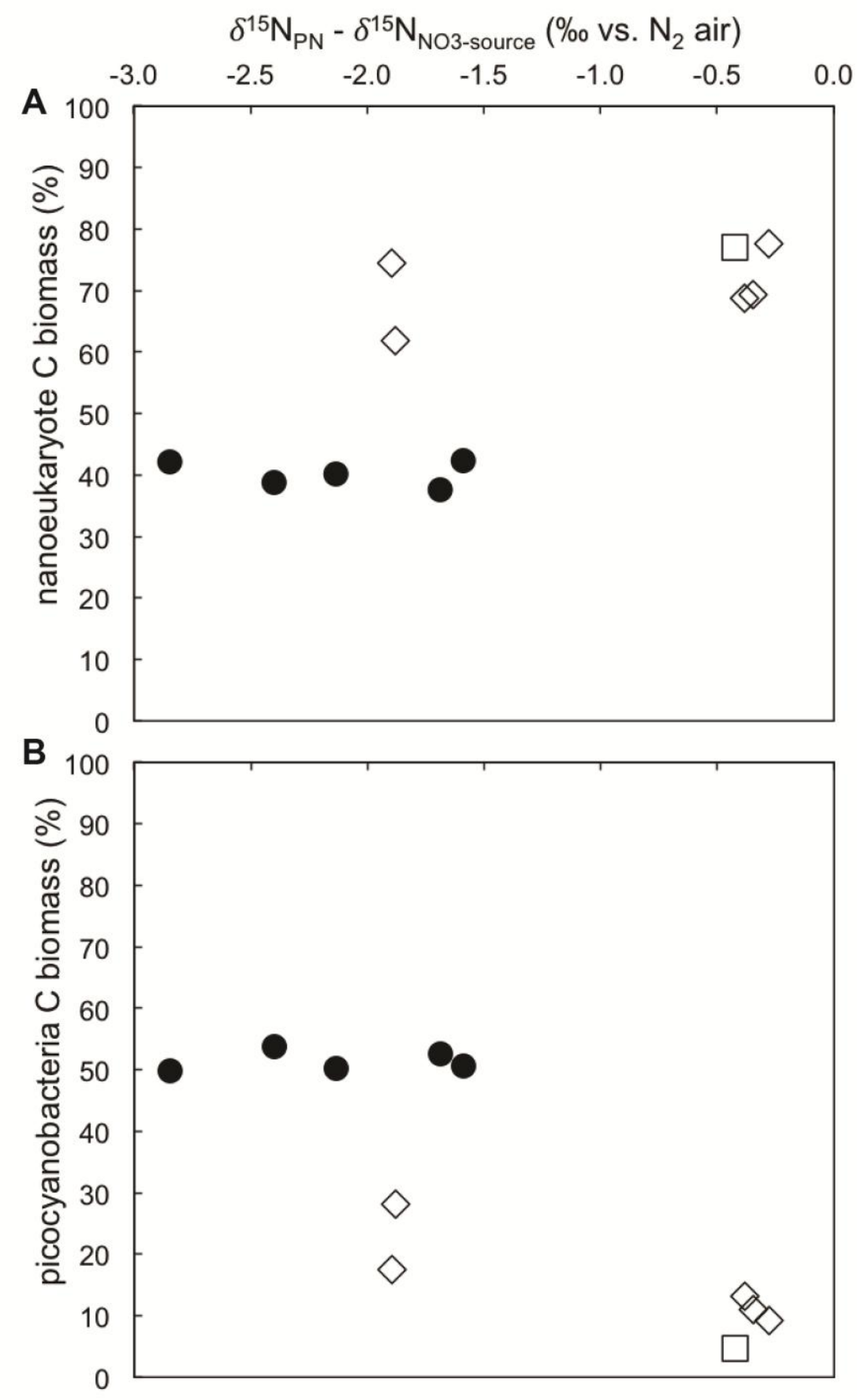


Figure 6. Depth section plots of (A) chlorophyll $a$ and (B) pico- and nanophytoplankton carbon biomass concentration along the transect course. Dotted profile samples are associated with station numbers listed at the top of the figure. The thick grey dashed line indicates the depth of the nitracline $\left(\left[\mathrm{NO}_{3}{ }^{-}\right]=300 \mathrm{nmol} \mathrm{I}^{-}\right.$ ${ }^{1}$ ) and the thick white dashed line represents the light compensation depth $\left(Z_{\text {Ic }}\right.$ at 0.17 mol PAR quanta $\mathrm{m}^{-2}$ day $^{-1}$ ).

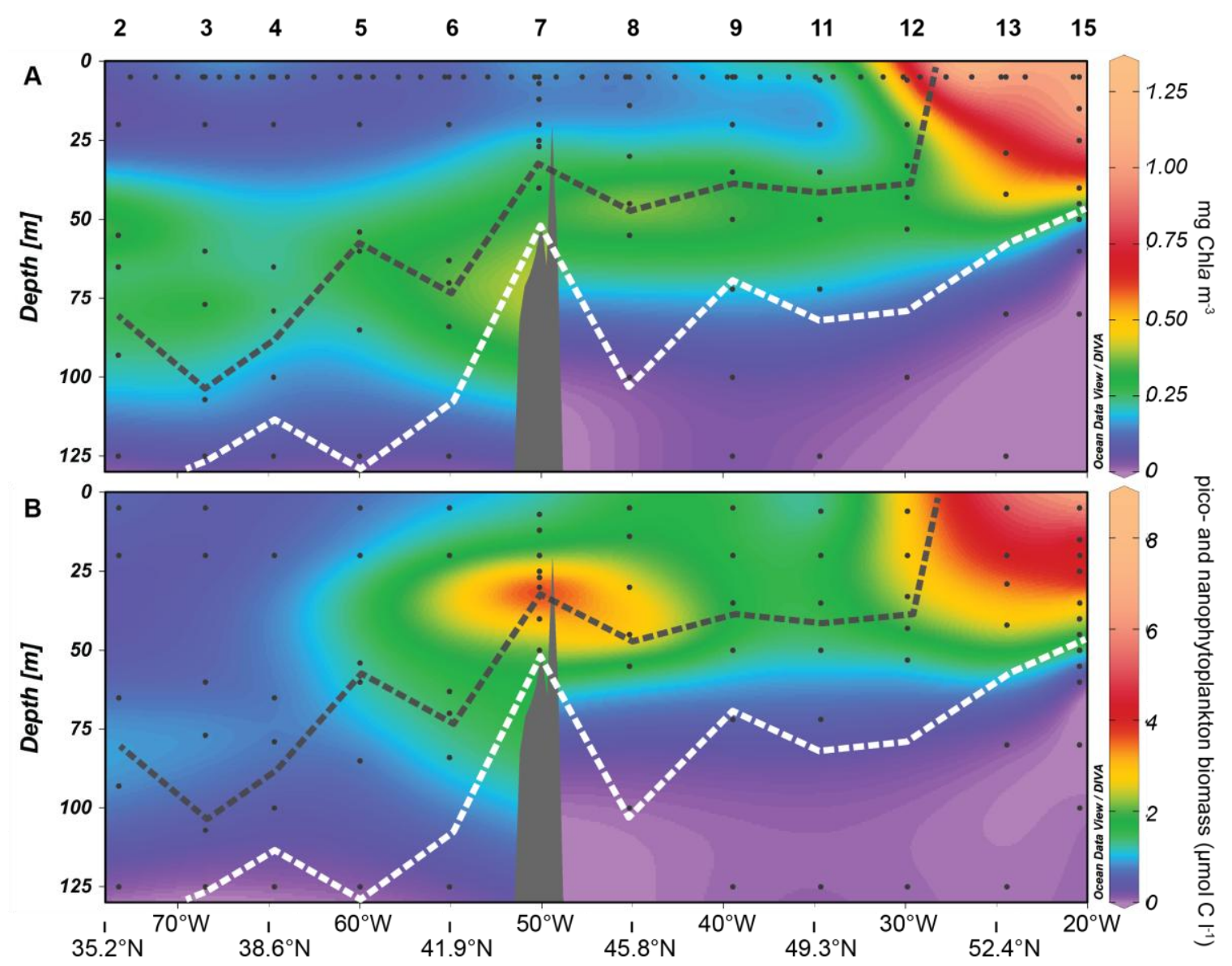


Figure 7. Depth-integrated chlorophyll $a$ ( $\Sigma$ Chla) in each size fraction $(<2 \mu \mathrm{m}, 2-20$ $\mu \mathrm{m}$ and $>20 \mu \mathrm{m}$ ) above the light compensation depth ( $\mathrm{Z}_{\mathrm{Ic}}$, see Table 1) as a percentage of the total integrated Chla measured at each station (solid black line).

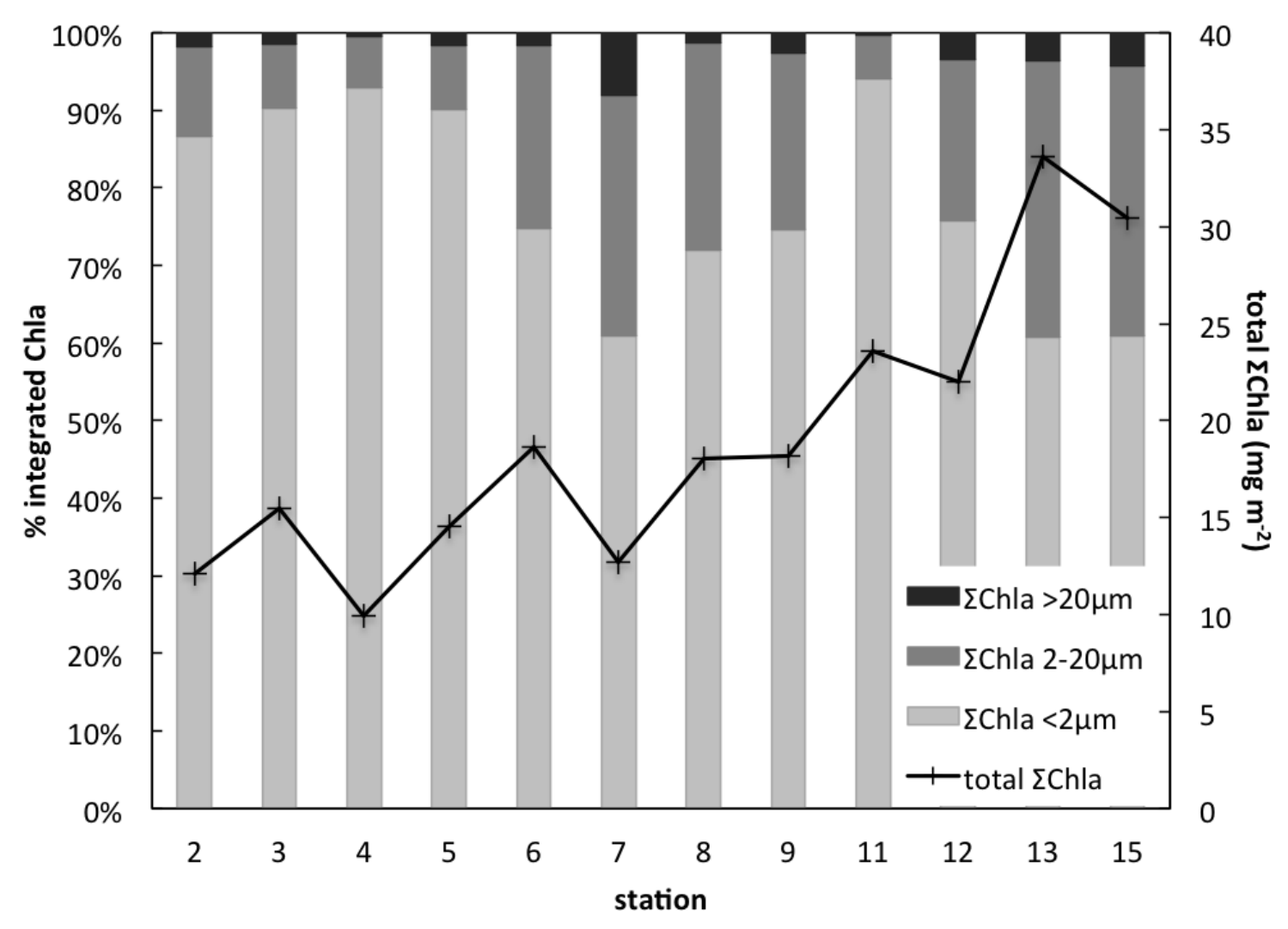


Figure 8. Depth section plots of the carbon biomass concentration of (A) Prochlorococcus, (B) Synechococcus, (C) picoeukaryotes, and (D) nanophytoplankton as enumerated by flow cytometry across the transect course. Dotted profile samples are associated with the station numbers listed at the top of the figure. The thick grey dashed line indicates the depth of the nitracline $\left(\left[\mathrm{NO}_{3}^{-}\right]=300 \mathrm{nmol} \mathrm{l}^{-1}\right)$. Note the 
difference in colour bar scale for each phytoplankton group.
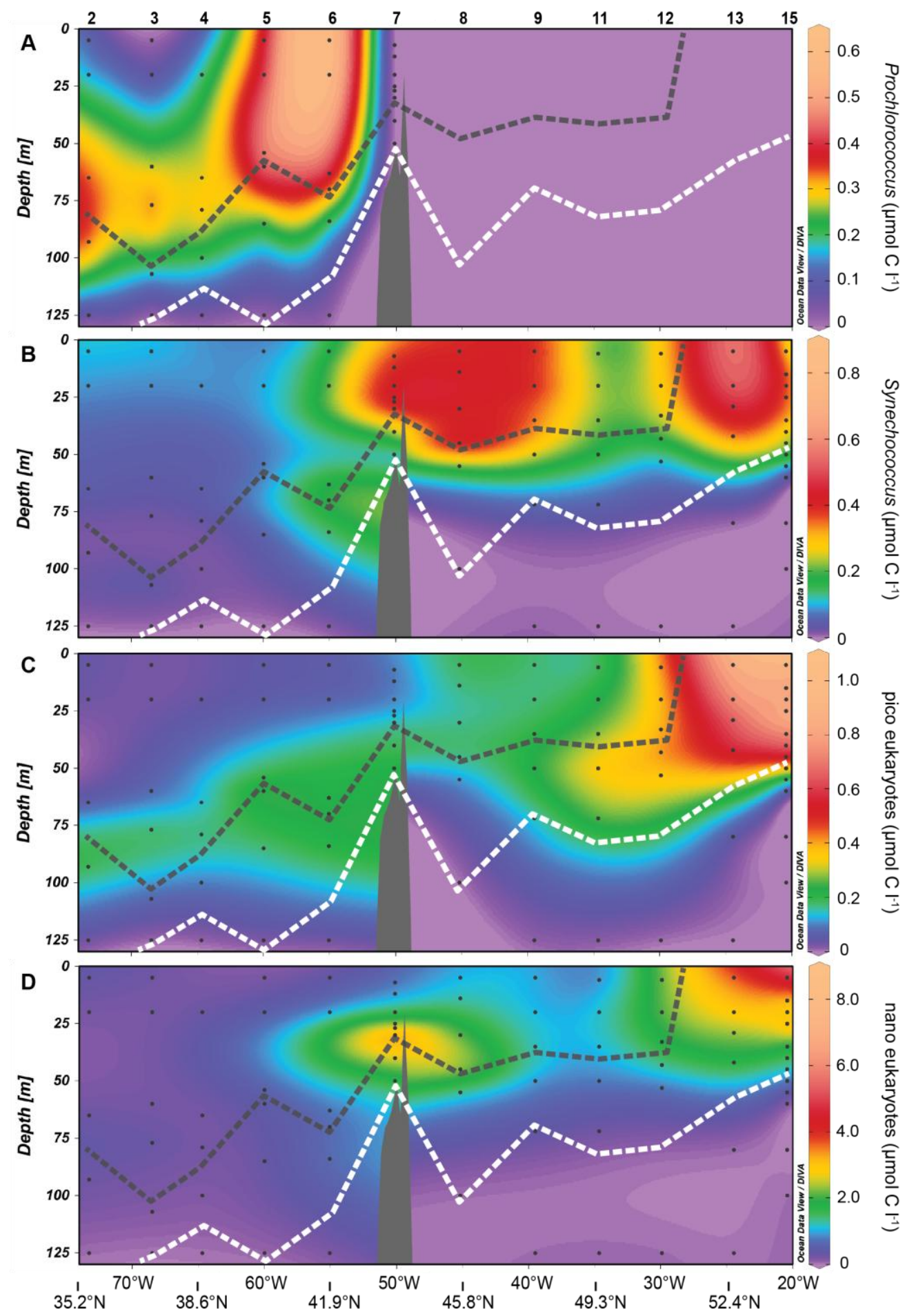

Figure 9. Depth section plots of the proportion of biomass represented by (A) Prochlorococcus, (B) Synechococcus, (C) picoeukaryotes, and (D) nanoeukaryotes as determined by flow cytometry. The thick grey dashed line indicates the depth of the 
nitracline $\left(\left[\mathrm{NO}_{3}^{-}\right]=300 \mathrm{nmol} \mathrm{l}^{-1}\right)$ and the thick white dashed line represents the light compensation depth ( $Z_{\text {Ic }}$ at 0.17 mol PAR quanta $\mathrm{m}^{-2}$ day $\left.^{-1}\right)$. Dotted profile samples are associated with the station numbers listed at the top of the figure. Samples with a potentially unrepresentative population estimates ( $<250$ nanophytoplankton cells counted) are greyed-out. Note that the different phytoplankton groups are plotted using different colour scales selected to emphasize their distribution patterns. 

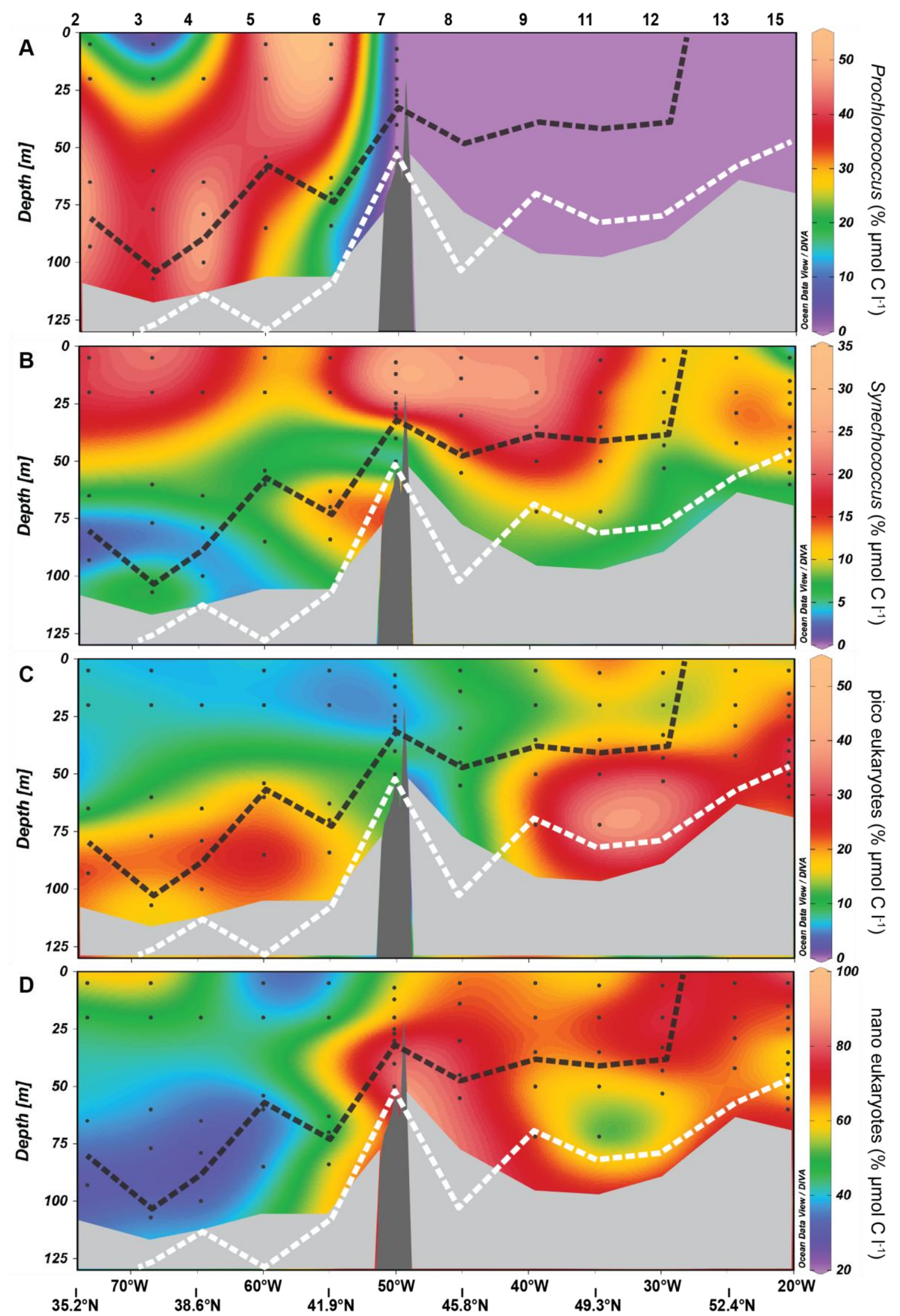
1.1 Figure 10. Depth section plots of $(\mathrm{A})$ inorganic carbon fixation rate (transport rate; $\rho$ DIC) and (B) inorganic carbon fixation rate normalised to flow cytometry-derived phytoplankton biomass (specific rate; VDIC). The thick grey dashed line indicates the depth of the nitracline $\left(\left[\mathrm{NO}_{3}^{-}\right]=300 \mathrm{nmol} \mathrm{l}^{-1}\right)$. Dotted profile samples are associated with the station numbers listed at the top of the figure.

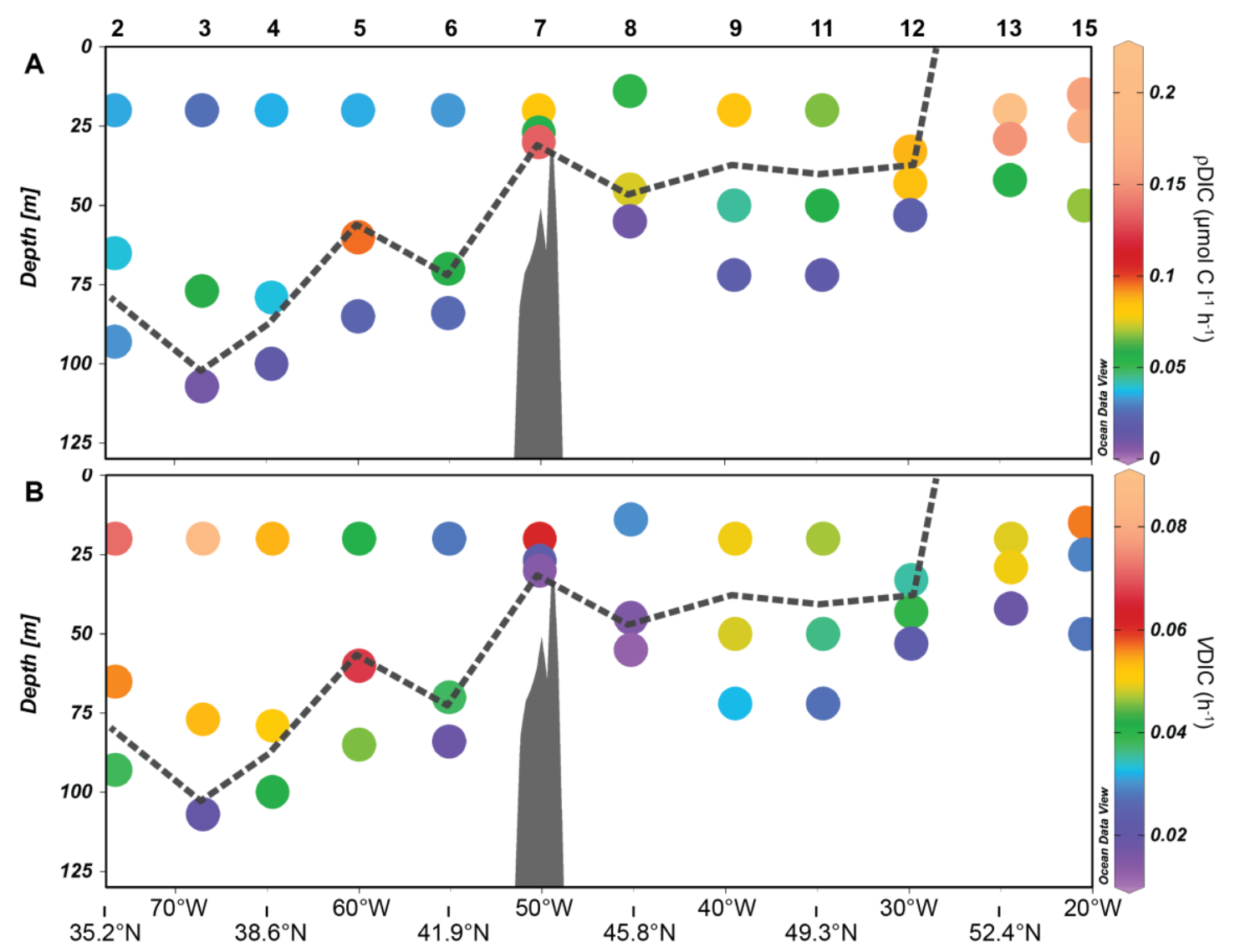


Table 1. Location and sampling date of transect stations. $Z_{\text {eu: }}$ euphotic zone depth at 1\% of surface PAR; MLD: mixed layer depth; $\mathrm{Z}_{\mathrm{Ic}}$ : light compensation depth; $\Sigma$ Chla: depth-integrated Chla from surface to $\mathrm{Z}_{\mathrm{Ic}}$.

\begin{tabular}{|c|c|c|c|c|c|c|c|c|c|c|}
\hline $\begin{array}{l}\text { transect } \\
\text { section }\end{array}$ & station & date & $\begin{array}{l}\text { latitude } \\
\left({ }^{\circ} \mathrm{N}\right)\end{array}$ & $\begin{array}{l}\text { longitude } \\
\left({ }^{\circ} \mathrm{W}\right)\end{array}$ & $\begin{array}{l}Z_{\mathrm{eu}} \\
(\mathrm{m})\end{array}$ & $\begin{array}{l}Z_{\text {Ic }} \\
(\mathrm{m})\end{array}$ & $\begin{array}{l}\text { MLD } \\
(\mathrm{m})\end{array}$ & $\begin{array}{l}\text { nitracline } \\
\text { depth }(\mathrm{m})\end{array}$ & $\begin{array}{l}300 \mathrm{nmol} \\
{\left[\mathrm{NO}_{3}^{-}\right] \mathrm{l}^{-1}} \\
\text { isopleth }(\mathrm{m})\end{array}$ & $\begin{array}{l}\sum \text { Chla } \\
\left(\mathrm{mg} \mathrm{m}^{-2}\right)\end{array}$ \\
\hline \multirow{5}{*}{ southwest } & 2 & $2013-08-23$ & 35.55 & 73.27 & 115 & 143 & 26 & 65 & 79 & 12.1 \\
\hline & 3 & 2013-08-24 & 37.44 & 68.51 & 103 & 126 & 33 & 107 & 101 & 15.5 \\
\hline & 4 & $2013-08-25$ & 38.78 & 64.71 & 120 & 115 & 45 & 79 & 85 & 9.9 \\
\hline & 5 & $2013-08-26$ & 40.27 & 60.00 & 106 & 130 & 30 & 54 & 57 & 14.6 \\
\hline & 6 & 2013-08-27 & 41.90 & 55.06 & 90 & 108 & 21 & 70 & 71 & 18.7 \\
\hline \multirow[t]{3}{*}{ shelf } & 7 & 2013-08-28 & 43.96 & 50.13 & $57^{*}$ & $57 *$ & 22 & 30 & 33 & 12.7 \\
\hline & 8 & 2013-08-29 & 45.74 & 45.17 & 83 & 101 & 17 & 45 & 46 & 18.0 \\
\hline & 9 & 2013-08-30 & 47.71 & 39.50 & 77 & 71 & 30 & 35 & 37 & 18.2 \\
\hline \multirow[t]{4}{*}{ northeast } & 11 & 2013-08-31 & 49.35 & 34.69 & 71 & 82 & 28 & 35 & 41 & 23.5 \\
\hline & 12 & 2013-09-01 & 50.93 & 29.90 & 70 & 79 & 38 & 33 & 37 & 22.0 \\
\hline & 13 & 2013-09-02 & 52.64 & 24.45 & 50 & 58 & 36 & 42 & 0 & 33.6 \\
\hline & 15 & 2013-09-03 & 54.02 & 20.44 & 52 & 47 & 39 & 45 & 0 & 30.4 \\
\hline
\end{tabular}

*Because of the low value of the derived light attenuation coefficient at station 7 , the bottom depth is listed instead of $\mathrm{Z}_{\mathrm{eu}}$ and ZIc. 
Table 2. Planktonic groups quantified by flow cytometry and distinguished based on their fluorescence and light scattering properties. These properties included chlorophyll (Chla) fluorescence (fluo.), phycoerythrin (PE) fluo., light side scatter (SSC) and forward scatter (FSC) signals. Nanoeukaryote phytoplankton (nanoEuks) include noPE-, PE-nanoEuk and Cocco (see text for explanation of abbreviations).

\begin{tabular}{|c|c|c|c|c|c|c|}
\hline planktonic group & $\begin{array}{l}\text { group } \\
\text { abbreviation }\end{array}$ & $\begin{array}{l}\text { cell size } \\
(\mu \mathrm{m})\end{array}$ & Chl fluo. & PE fluo. & SSC vs. FSC & $\begin{array}{l}\text { stained } \\
\text { DNA fluo. }\end{array}$ \\
\hline $\begin{array}{l}\text { non-PE nanoeukaryote } \\
\text { phytoplankton }\end{array}$ & noPE-nanoEuk & $\sim 2.5-14$ & yes & no & low & - \\
\hline $\begin{array}{l}\text { PE nanoeukaryote } \\
\text { phytoplankton }\end{array}$ & PE-nanoEuk & $\sim 2.5-14$ & yes & yes & low & - \\
\hline coccolithophore & Cocco & $\sim 2.5-14$ & yes & no & high & - \\
\hline $\begin{array}{l}\text { picoeukaryote } \\
\text { phytoplankton }\end{array}$ & picoEuk & $\sim 1-2.5$ & yes & no & low & - \\
\hline Synechococcus & - & $\sim 1$ & yes & yes & low & - \\
\hline Prochlorococcus & - & $<1$ & yes & no & low & yes \\
\hline heterotrophic bacteria & - & $<1$ & no & no & low & yes \\
\hline
\end{tabular}


Table 3. Pearson correlation coefficient between different biogeochemical and/or physical variables measured in the upper $145 \mathrm{~m}$ of the water column. Heterotrophic bacterial cell abundance (het. bact. cell abund.), temperature (T), relative carbon biomass contribution of nanoeukaryote phytoplankton (\%nanoEuk C) to total flowcytometric phytoplankton biomass (FCM phyto C), relative carbon biomass contribution of Prochlorococcus and Synechococcus to FCM phyto C (\%picocyano C), upper ocean mass-weighted average $\delta^{15} \mathrm{~N}$ of suspended PN $\left(\delta^{15} \mathrm{~N}_{\mathrm{PN}}\right)$ minus the $\delta^{15} \mathrm{~N}$ of the subsurface nitrate source $\left(\delta^{15} \mathrm{~N}_{\mathrm{PN}}-\right.$ $\left.\delta^{15} \mathrm{~N}_{\mathrm{NO3}}\right)$.

\begin{tabular}{|c|c|c|c|c|c|}
\hline variable y & variable $\mathrm{x}$ & Pearson's $r$ & $p$ & $\mathrm{n}$ & data subset \\
\hline nitracline depth & $\mathrm{Z}_{\mathrm{eu}}$ & 0.56 & $>0.05$ & 12 & upper $125 \mathrm{~m}$ \\
\hline nitracline depth & $\mathrm{Z}_{\mathrm{Ic}}$ & 0.64 & $<0.05$ & 12 & upper $145 \mathrm{~m}$ \\
\hline nitracline depth & MLD & 0.18 & $>0.05$ & 12 & upper $125 \mathrm{~m}$ \\
\hline nitracline depth & $\delta^{15} \mathrm{~N}_{\mathrm{PN}}$ & -0.73 & $<0.01$ & 11 & above nitracline depth or MLD \\
\hline nitracline depth & $\delta^{15} \mathrm{~N}_{\mathrm{PN}}-\delta^{15} \mathrm{~N}_{\mathrm{NO}}$ & -0.53 & $>0.05$ & 11 & above nitracline depth or MLD \\
\hline \%nanoEuk C & $\delta^{15} \mathrm{~N}_{\mathrm{PN}}$ & 0.91 & $<0.001$ & 11 & above nitracline depth or MLD \\
\hline \%nanoEuk C & $\delta^{15} \mathrm{~N}_{\mathrm{PN}}-\delta^{15} \mathrm{~N}_{\mathrm{NO} 3}$ & 0.75 & $<0.01$ & 11 & above nitracline depth or MLD \\
\hline \%picocyano C & $\delta^{15} \mathrm{~N}_{\mathrm{PN}}$ & -0.93 & $<0.001$ & 11 & above nitracline depth or MLD \\
\hline \%picocyano C & $\delta^{15} \mathrm{~N}_{\mathrm{PN}}-\delta^{15} \mathrm{~N}_{\mathrm{NO}}$ & -0.84 & $<0.005$ & 11 & above nitracline depth or MLD \\
\hline POC & $\mathrm{PN}$ & 0.91 & $<0.001$ & 33 & 55,30 and $1 \%$ light depths \\
\hline POC & FCM phyto $\mathrm{C}$ & 0.91 & $<0.001$ & 36 & 55,30 and $1 \%$ light depths \\
\hline POC & Chla & 0.83 & $<0.001$ & 34 & 55,30 and $1 \%$ light depths \\
\hline het. bact. cell abund. & FCM phyto C & 0.85 & $<0.001$ & 94 & upper $125 \mathrm{~m}$ \\
\hline het. bact. cell abund. & Chla & 0.84 & $<0.001$ & 81 & upper $125 \mathrm{~m}$ \\
\hline het. bact. cell abund. & $\rho \mathrm{DIC}$ & 0.76 & $<0.001$ & 36 & 55,30 and $1 \%$ light depths \\
\hline$\rho D I C$ & POC & 0.70 & $<0.001$ & 36 & 55,30 and $1 \%$ light depths \\
\hline$\rho D I C$ & Chla & 0.76 & $<0.001$ & 34 & 55,30 and $1 \%$ light depths \\
\hline$\rho D I C$ & FCM phyto $\mathrm{C}$ & 0.73 & $<0.001$ & 36 & 55,30 and $1 \%$ light depths \\
\hline VDIC & $\mathrm{T}$ & 0.70 & $<0.001$ & 36 & 55,30 and $1 \%$ light depths \\
\hline VDIC & \%nanoEuk C & -0.42 & $<0.05$ & 36 & 55,30 and $1 \%$ light depths \\
\hline VDIC & \%nanoEuk C & -0.46 & $<0.05$ & 24 & 55 and $30 \%$ light depths \\
\hline VDIC & \%nanoEuk C & -0.80 & $<0.005$ & 12 & $30 \%$ light depth \\
\hline
\end{tabular}


\%nanoEuk C

\%nanoEuk C

\%nanoEuk C
$-0.77$

$-0.77$

$-0.89$
$<0.001$

$<0.001$

$<0.001$
55,30 and $1 \%$ light depths

55 and $30 \%$ light depths

$30 \%$ light depth 